\title{
Human Perceptions of Recycled Textiles and Circular Fashion: A Systematic Literature Review
}

\author{
Melissa Monika Wagner* and Tincuta Heinzel (D) \\ School of Design and Creative Arts, Loughborough University, Loughborough LE11 3TU, UK; \\ T.Heinzel@lboro.ac.uk \\ * Correspondence: M.M.Wagner@lboro.ac.uk
}

Received: 5 November 2020; Accepted: 16 December 2020; Published: 18 December 2020

\begin{abstract}
The textile and fashion industry has had significant technological developments but is currently criticised for its environmental and social impacts and for being a major contributor to waste. The rise of the circular economy (CE) has promoted more sustainable concepts, including the trending of recycling strategies to add value to the textile and plastic waste. However, adding value to products and for users implies technical upscaling and clear communication about the benefits of recycling. This paper presents a systematic literature review (SLR) and explores the state of the art of recycled textiles (RT) and circular fashion (CF) as perceived by humans. The literature review was performed on the basis of journal articles, book chapters, and conference papers using the ScienceDirect (SD) and Web of Science (WoS) databases. The review identified that a significant proportion of consumers from different countries have a basic understanding of sustainable products but that there have been differences in consumers' attitudes towards sustainable purchase, use, consumption, and post-purchase behaviour. Diverse and even contradictory results occurred concerning the relationships between RT and CF and their perceived product attributes in terms of quality and functionality, as well as social-cultural factors. Manufacturers' and brands' perceived values of RT were observed to be influenced by different factors on the basis of the recycling system and cultural values, while designer attitudes towards sustainability were observed to be influenced by external factors. This review contributes to the creation of three main implications in terms of environmental impact and awareness, including actions and concrete proposals for RT and CF.
\end{abstract}

Keywords: recycled textiles; circular fashion; textile waste; recycling; perception; consumer behaviour

\section{Introduction}

The high consumption and disposal of fast fashion are creating large numbers of post-consumer textile waste from end-consumers. Estimations by the Waste and Resources Action Programme (WRAP) report [1] refer to 1,130,000 tonnes of clothing and household textile purchases and a carbon footprint of 26.2 million tonnes $\mathrm{CO}_{2} \mathrm{e}$ in 2016, with the UK having the highest consumption rate in the EU with $26.7 \mathrm{~kg}$ per capita in 2010 [2]. Moreover, the fashion and textile industry generates industrial by-product textile materials in terms of fibres, fabrics, and overproduction, resulting in post-industrial or pre-consumer waste. Oil-based fibres estimate for 63 per cent of the total global fibre consumption of 108 million tonnes in 2019, and further market growth is expected [3]. Polyester is the most crucial fibre worldwide, considering its market share of around $51.5 \%$ and its production volume of more than 55.1 million tonnes in 2018 [4]. It has been claimed that polyester is an environmentally friendly synthetic fabric as it can be recycled if unblended or made from polyethylene terephthalate (PET) bottles [5]. In fact, single-use PET bottles are widely available, and brands and retailers started using them to make clothing. In 1993, Patagonia [6] launched their first ever recycled polyester fleece "PolarFleece" made of recycled polyester from plastic soda bottles. The most common recycled 
synthetic fibres are recycled polyester and polyamide [4]. Polyester is also one of the most studied recycling materials, besides cotton [7]. The current plastic production and disposal behaviour is significantly impacting the environment through resource depletion of fossil fuels and large amounts of carbon emissions [8], as well as the disruption of marine ecosystems predicting more plastic than fish in the ocean by 2050 [9]. The fast consumption of fashion made from synthetic fibres accelerates this trend. The globalised industry has led to the low-cost production of disposable fashion. Moreover, as recently released by the Civil Society Shadow European Strategy, the current health and economic crisis shows that "the textile supply-chain is particularly hard hit" [10]. The COVID-19 pandemic has again increased plastic demand and reliance [11], pointing up barriers of the current system in terms of resource-dependency. Lockdowns have created more supply than demand for second-hand clothes among consumers and industry. New visions and models beyond this current situation are under development but need more political support.

Hence, companies and brands have realised the need to reduce waste and have been reintroducing the recycling of textile scraps [12]. More sustainable manufacturing and higher rates of recycling, along with consumer awareness, are key elements to support sustainable development and lower the impact of the fashion and textile industry [13]. Consumers are widely seen to play a vital role to drive sustainability, such as the EU Textile Strategy, whereby consumers are one of the " 12 key points for circular textiles" [14]. "Globalization, consumerism, and recycling" and their influence on the clothing life cycle present different scenarios [15]. Recycling aims to reduce landfill or incineration, as well as the sourcing of virgin materials. Textile waste can add value to the industry, as some companies perceive cost benefits through saving landfill charges or donating textile waste [16]. Nevertheless, even though textiles and clothing are claimed to be nearly fully recyclable $[16,17]$, less than $1 \%$ of clothing textile material is recycled into new clothes [18]. This percentage means that around GBP 140 million worth of clothing is lost through landfills per year [19]. However, the analysis of the recycled textile material ratio is complex, with some experts assessing an even lower share of the $1 \%$, e.g., $<0.1 \%$ [18]. Still, recycling barriers such as mixed waste streams are challenging the industry [20].

Further challenges remain such as the discharge of microplastics and their potential toxicity. Synthetic textiles such as acrylic, polyamide, and polyester are primary contributors to the microplastic release in the environment and ocean. Synthetic clothing can shed during washing and cause plastic microfiber pollution, whereby fleece fabric, compared to other knitted fabrics, sheds considerably more fibres-around 110,000 fibres per garment and wash for a PET fleece [21]. Besides synthetic plastic in terms of polyester, acrylic, polyamide, polyethylene, and polypropylene, natural and regenerated cellulose fibres have been found to shed microfibres in southern European deep seas [22]. Furthermore, it is assumed that textile waste can contain potentially unsafe chemicals [23], making it necessary to develop appropriate recycling methodologies and technologies to remove restricted chemical residues.

Thus, one solution to cope with the issue of textile waste is to establish recycling of synthetics and to develop large-scale textile-to-textile recycling [4]. There are different methods of textile recycling from several suppliers with varieties of outcomes regarding price and quality [4]. Recycling is defined in the EU legal acts such as "The European Waste Framework Directive" (Directive 2008/98/EC) [24]. The definition of recycling refers to material recovery and includes recovery other than energy recovery, in terms of reuse, recycling and backfilling, and other forms of material recovery [25]. Waste management is based on the "waste hierarchy" with the following priorities (from most to least preferred option): prevention, (preparing for) reuse, recycling, recovery, and disposal (landfilling and incineration) [26]. The definition and distinction of the different terms are essential to apply this legislation. However, there is no common definition, and many descriptions are used for "textile recycling" such as "the reprocessing of pre- or post-consumer textile waste for use in new textile or non-textile products $(\ldots)$ also including the recycling of non-textile materials and products $(\ldots)^{\prime \prime}[7]$ (p. 2). The global Non-profit Organization Textile Exchange describes "preferred fibres" [4], such as "preferred recycled synthetic fibres" defined as "synthetic fibres that have been manufactured from materials recovered from the waste stream" [27]. The Ellen MacArthur Foundation [18] describes a 
long-term vision for a new circular textiles economy by aiming for closed-loop clothing recycling, described as "clothing fibres that are recycled back into fibres in clothing production" (p. 122). Moreover, the Mistra Future Fashion research program focused on a circular fashion economy and presented several reports and papers on the topic of textile recycling, including a comprehensive "topology of textile reuse and recycling", which summaries related terminology of textile recycling from fabric and fibre recycling to polymerisation [7], and "general terminology used in the textile area" in the two reports "The Fiber Bible Part 1 and 2" [28]. Recycling of textiles reduces "environmental contacts" in terms of impacts, but different scenarios provide more or less environmental benefits $[7,28]$. In comparison to virgin textile fibres, the authors summarised that textile reuse and recycling have environmental benefits in terms of avoided production-environmental-friendly textiles are supposed to be manufactured with clean processes, and high replacement rates are essential for recycling, as well as short transports and long use phases for reuse, with recycling including non-textile materials and products [7]. The use phase estimates one-third of the environmental impacts throughout a product's life, according to the European Clothing Action Plan (ECAP) [29]. Besides environmental and business benefits, there are also advantages for consumers. Filho et al. [30] reviewed the socio-economic advantages of textile reuse and recycling models. Economic and social benefits were "empowering consumers, suppliers and involved workers as well as adding value to businesses and communities" (p. 4). Furthermore, it can include design as a "complimentary strategy", such as "Design for Cyclability". This strategy designs virgin materials for future recycling and closed-loop systems in terms of "recyclable fashion" with a "short life duration". It includes design for recycling, up-cycling, design for mono materiality, and design for disassembly [31]. This design strategy could be applied for fast fashion consumers of "disposable fashion", as pre-consumer waste can increase volumes of particular styles [30].

Further substantial work is necessary to develop synthetic textile recycling. Historically, synthetic textiles were recognised due to their "utilitarian virtues" [32] (p. 208). Recycled synthetics such as polyester are still positively perceived for their functional or utilitarian attributes in terms of "durable" and "economical" characteristics [33]. Synthetic fibres have good physical and chemical properties such as high strength, durability, water, stain, or heat resistance. Besides their excellent performance, polyester fibres are easy to process and are cost-effective [34]. It is claimed that there is no significant difference between virgin polyesters and recycled polyesters in terms of high strength, durability, versatility, and performance [35]. PET fibres from bottle-grade recycled co-polymer PET material have similar properties as fibres produced from fibre-grade virgin homo-polymer PET [36]. Polyester's wear and tear resiliency make it a long-lasting fabric, which is a critical property to enable a more extended use phase and lower environmental impacts by cutting waste and new resources. However, when disposed of quickly, its non-biodegradability and slow degradation process becomes a drawback. Some fast fashion consumers intend to wear their garments only "one time" [37] (p. 149), "a season", or "will never wear it" (p. 153), and expect their clothing to last only "a few wears" (p. 156) before disposal. The active use time for clothing in the UK is an average of 3.3 years [38]. Thus, textile reuse and recycling are considered essential solutions for fast fashion. There are two leading standards for the validation of textile recycling content-the Recycled Claim Standard (RCS) sets requirements of the recycled content, and the Global Recycled Standard (GRS) refers to the International Organization for Standardization (ISO) 14021 definition of recycled content and includes social, environmental, and chemical requirements. Safety and quality are essential consumer attributes. Mechanically recycled post-consumer waste fibres for new garments can be perceived as unhygienic or unsafe by some brands and consumers [39]. It seems that a vast range of social variables and factors impact the consumer relationship with virgin and recycled polyester, creating positive and negative attitudes and behaviour, including an increasing or decreasing demand towards recycled synthetics. The efforts of marketing and advertising, as well as trends and media coverage, should be considered to understand consumer perception and purchasing behaviour. The choice between virgin and recycled textile products depends on the perceived benefits or disadvantages of product attributes. 
There is a cultural shift towards textiles, including cultural expression and renewed interest in material processes $[12,40]$. Awareness is needed for adaption to stimulate new experimentation [41]. Besides visual response, touch and haptic perception have become central elements in art and craft. The textile artist and weaver Anni Albers (1899-1994) was best known for her design work in the context of the Bauhaus in Germany and the Black Mountain College in the USA [42]. Perception is a process that can include sensory experiences [41,43], whereby information is selected, organised, and interpreted by the receiver to form a reaction [44]. Often, branded sustainable products are designed to create perceived quality and added emotional value that impact buying behaviour: Mihaly Csikszentmihalyi, the author of the psychological concept of flow, researched happiness such as the phenomenological meaning of situational happiness in different cultures [45]. For example, Nicolao et al. [46] studied whether experiential purchases could make consumers happier than material purchases. There have been several studies on the consumption of sustainable fashion and textiles and the relation of product attributes, consumer attitudes, and behaviour [47-52]. For example, the fibre content of clothing is one of the most important factors influencing consumers' purchase intention [53]. In the case of full consumer satisfaction of personal needs and other factors, communication in terms of additional information on environmental benefits can add value $[54,55]$. Similarly, the communication of the benefits of fibre-to-fibre recycling can avoid potential negative assumptions [39]. Therefore, consumers' awareness, attribute importance, and perceived value become crucial for the success of recycled synthetic textile products. Rucker's [56] review on "consumer perceptions of recycled textile fibres" considered consumers' positive and negative attitudes and their relation to consumer characteristics as well as external factors such as media attention, influencing "the green market". Social media and its effect on sustainable fashion consumption were studied by Strähle and Gräff [57]. Furthermore, Rucker [56] compared perceptions of "traditional" and "recycled" textile fibres and materials, looking at the fibre content; material blend and label prices [53]; fibre performance [58]; premium prices, choices, or availability; aesthetics [55]; and fashion-image and credibility [59]. Researchers studied the perception of different economic models including waste disposal and recycling in terms of circular business models, such as the Circular Economy (CE) [60,61], and its definition, trends, and relationship to other research streams such as cradle-to-cradle by McDonough and Braungart [62]. Circularity is considered crucial, and researchers claim that "recycling is linear" if no circular strategy is adopted, including reuse, recycling service models, and transferring skilled remanufacturing processes (people to create awareness) [63]. According to the production and consumption cycle, sustainability varies within fashion business models [64].

Consumers have become more reactive, showing awareness and concerns, as well as willingness to change behaviour and use alternatives. Correspondingly, the textile industry, including brands and retailers, has developed sustainable alternatives such as recyclable or renewable materials and promoted sustainable strategies. The case of synthetic fibres throughout history demonstrates contrary perceptions-plastic as both a "wonder" and a "threat". Likewise, consumer response is often controversial, and it is complex to identify the individual rationales behind this phenomenon. Consequently, some academics have tried to collect a range of perceptions regarding textile materials and designs. This research aims to understand the perceptions of recycled textiles (RT) and circular fashion (CF) within the context of the $\mathrm{CE}$ and from a historical and cultural perspective.

This review paper has the following objectives:

1. To assess the awareness and value-meaning of sustainable concepts and fashion models.

2. To evaluate the positive and negative attitudes towards environmental and socio-economic issues within the production processes and consumption activities related to consumer use, appreciation, textile waste, disposal, and recycling.

3. To determine the state of the art on the response to textile waste and recycling including cultural and historical perspectives. 
This review paper has the following research questions:

1. What is the consumer and the industry awareness of environmental and social issues related to textile waste, and how is this measured?

2. What are the positive and negative consumer and industry attitudes towards RT and CF concepts?

3. What are the contexts of responses to textile waste including cultural and historical perceptions, and what kind of strategies should be adopted in the future to facilitate textile recycling in terms of consumers and textile manufacturers, brands, and retailers' attitudes? What are some of the critical issues in the conducted studies?

\section{Materials and Methods}

This systematic literature review (SLR) applied the fundamental step by step process set out by Arksey and O 'Malley [65] and as implemented by Moher et al. [66]. Existing reviews related to textile reuse and recycling guided the literature search approach such as by Sandin and Peters [7] and Filho et al. [30], analysing environmental impact and socio-economic advantages, respectively. The methodology adapted the following steps of topic selection, identification of research statement, identification of sources, critical evaluation of relevant studies, as well as screening and sorting of relevant data. The final step included the organisation of data and summary of review findings in a sequential manner according to the research objectives and questions. In this coordinated approach, the research questions were directly related to the topic of RT and CF. This method can help to provide reliable, detailed, and diverse information by identifying new trends within the research area.

\subsection{Literature Collection}

An online literature search was performed using the most renowned databases for scientific peer-reviewed literature-ScienceDirect (SD) and Web of Science (WoS), which were selected and screened for relevant publications including journal articles, book chapters, and conference papers to comprise a significant amount of literature data. This step included the identification and selection of sources for the literature review. The search was performed on predetermined combinations of keywords along with Boolean operators ("AND", "OR") that were designed for the selection of literature. The selection of keywords was carried out on the basis of the relevance to the topic of textile recycling and words that are most commonly used in research articles and by researchers. Therefore, an evaluation of existing review papers related to textile reuse and recycling $[7,13,30,61]$ and their keywords and search strings was carried out (see Table 1).

Sandin and Peters [7] reviewed studies of textile reuse and recycling and the environmental impact. The most studied recycling type was fibre recycling (57\%), followed by polymer/oligomer recycling $(37 \%)$, monomer recycling $(29 \%)$, and fabric recycling $(14 \%)$, and the most studied materials were cotton $(76 \%)$ and polyester $(63 \%)$. In another study, the authors studied mixed textile recycling in Sweden and its environmental benefits [20]. Next, Filho et al. [30] adapted this keyword search, including environmental, economic, and social benefits. Moreover, Hole and Hole [13] reviewed recycling literature in the databases SD and Google. Finally, Jia et al. [61] reviewed the CE in the textile and apparel industry using keywords in two different search strings.

Accordingly, the selected databases SD and the WoS were screened with the following search term that was applied in this study to find the literature: (perception OR attitude OR response OR awareness) AND (recycled OR recycling) AND (textile OR fibre OR fashion OR garment) (see Table 1 for the references). The search focused on article types in terms of research articles, book chapters, and conference abstracts. The SD database was screened using keywords within the title, abstracts, and keywords (title, abstract, or author-specified keywords) and had no temporal restrictions (year(s): N/A). A previous search within all fields (find articles with these terms) resulted in too many irrelevant results, with 67,654 total results. The WoS Core Collection was screened through keywords within all fields (ALL FIELDS) and with no temporal restrictions (timespan: all years). 
Table 1. Keywords in review articles related to textile reuse and recycling.

\begin{tabular}{|c|c|}
\hline Author & Search String \\
\hline Sandin and Peters [7] & $\begin{array}{c}\text { [“life cycle assessment" OR “life cycle analysis" OR LCA OR } \\
\text { (environmental OR energy) AND (assessment OR evaluation OR } \\
\text { analysis) AND (textile OR clothing OR garment OR fashion OR apparel) } \\
\text { AND (recycling OR reuse OR "collaborative consumption" OR "second } \\
\text { hand" OR library OR sharing OR leasing)]. }\end{array}$ \\
\hline Filho et al. [30] & $\begin{array}{c}\text { [textile OR clothing OR garment OR apparel OR fibre OR microfiber OR } \\
\text { fabric] AND [waste OR reuse OR recycling] AND [world OR global OR } \\
\text { Europe OR NORDIC OR Brazil] AND [impacts OR pollution OR } \\
\text { barriers OR challenges OR disadvantages] AND [environmental benefits } \\
\text { OR economic benefits OR social benefits] AND [businesses OR workers } \\
\text { OR consumers OR local community OR society]. }\end{array}$ \\
\hline Hole and Hole [13] & $\begin{array}{l}\text { ["recycling AND/OR reuse in textile industry AND/OR production", } \\
\text { "sustainable textile AND/OR industry", "renewable AND/OR solar } \\
\text { energy AND/OR use in textile industry", "fashion problem AND/OR } \\
\text { demand AND/OR environment", "consumer awareness AND/OR } \\
\text { behavior in textile production AND/OR fashion industry"]. }\end{array}$ \\
\hline \multirow[t]{2}{*}{ Jia et al. [61] } & $\begin{array}{l}\text { String 1: [apparel or garments or clothing or dress or textile or*wear or } \\
\text { clothes or attire or outfit] AND ["circular economy" or CE or "circular } \\
\text { business" or "closed loop" or "cleaner production" or "industrial } \\
\text { ecology" or "green economy" or sustain* or "green production" or } \\
\text { "reverse logistic" or "recycling" or "recovery"]; }\end{array}$ \\
\hline & $\begin{array}{l}\text { String 2: [apparel or garments or cloth* or dress or textile or *wear or } \\
\text { fashion or outfit] and ["corporate social responsibility" or CSR or "triple } \\
\text { bottom line" or environment* or social* or sustainab* or green] AND } \\
\text { ["supply chain" or "value chain" or procurement or purchas"]. }\end{array}$ \\
\hline This SLR & $\begin{array}{c}\text { [(perception OR attitude OR response OR awareness) AND (recycled } \\
\text { OR recycling }[7,13,30,61] \text { AND (textile }[7,13,30,61] \text { OR fibre }[30] \text { OR } \\
\text { fashion }[7,13,61] \text { OR garment }[7,30,61])]\end{array}$ \\
\hline
\end{tabular}

* The asterisk is a wildcard used to broaden the search by representing variable single characters.

Then, the next step of screening and sorting of relevant data took place. After conducting an in-depth literature survey, we implemented exclusion criteria to shape the literature review. Identified studies which were not available were eliminated from an examination, as well as articles which provided duplicated studies from the same author, or studies on similar research questions on identical datasets. Furthermore, those studies which were only related to consumer preferences referring to textiles but not subjected to the theme of RT or CF were also eliminated. The inclusion and exclusion criteria are summarised in Table 2.

Table 2. The inclusion and exclusion criteria in the systematic literature review (SLR), adapted from Adro and Leitão [67].

\begin{tabular}{cc}
\hline Inclusion Criteria & Exclusion Criteria \\
\hline SD and WoS database from start of indexation until September 2020; & Full-text not available and duplicated studies; \\
[(perception OR attitude OR response OR awareness) AND (recycled OR & \\
recycling) AND (textile OR fibre OR fashion OR garment)] in title, abstracts, & Grey literature; Publications not directly related to RT and CF. \\
and keywords in the SD database, and in all fields in the WoS database; & \\
Research articles, book chapters, and conference abstracts; & \\
English language publication. & \\
\hline
\end{tabular}

Finally, after analysing the information obtained from the databases, we conducted the first search, which resulted in several documents that were screened and evaluated for relevancy by analysing the abstracts, leading to a significant decrease in sample size. Moreover, 3 articles that were double in the 2 databases were excluded. Figure 1 shows the selection steps for the reviewed articles. 


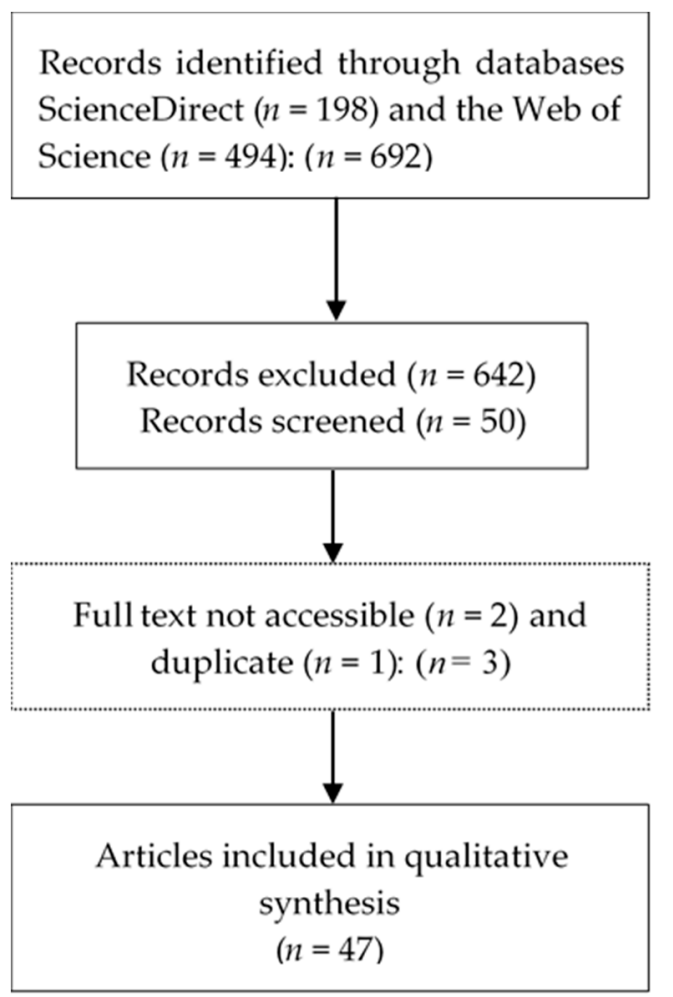

Figure 1. Selection steps for the reviewed articles.

SD resulted in 198 articles, and the WoS database returned 494 results. Thus, 692 records were generated, of which 642 publications were excluded as being not relevant to perception studies of textile recycling, including 2 articles where the full text was not accessible. Moreover, 1 conference proceeding was deleted while its journal paper was selected. In sum, 47 studies were selected for this review, which are listed in Appendix A.

Furthermore, network visualisation of the bibliometric data was created to identify common topics among the 40 selected research articles. The VOSviewer version 1.6.15, an open-source software for exploring bibliometric maps, was used to extract the most frequent and similar terms from the title and abstract of the research articles [68].

\subsection{Descriptive Analyses}

\subsubsection{Trends of Reviewed Articles}

The analysis of the articles showed that there was an increase in the number of publications after the year 2016. This finding indicates rising attention to the research area of RT and CF. Generally, the concept of the $\mathrm{CE}$ has gained increasing awareness in politics and science with growing publications over the past years [69]. In Figure 2, the distribution of the 47 papers in the year of publication is shown.

The 40 reviewed research articles were published in the Journal of Cleaner Production (4 times), Resources Conservation and Recycling, and Sustainability (3 times), as well as in the Autex Research Journal, International Journal of Consumer Studies, Journal of Product and Brand Management, Journal of The Textile Institute, Sage Open, and the Textile Research Journal (2 times). The 3 journals most often selected relate directly to the reviewed research field, covering research on cleaner production, environmental, and sustainability research and practice (Journal of Cleaner Production); sustainable management and conservation of resources (Resources Conservation and Recycling); as well as environmental, cultural, economic, and social sustainability of human beings, and studies related to sustainability and sustainable development (Sustainability). For example, the growing trend of publications related to the CE was recorded for the Journal of Resources, Conservation and Recycling [69]. Other notable contributions to 
sustainable recycled textile fibres, waste, and perceptions have come from additional sources such as books and proceeding papers.

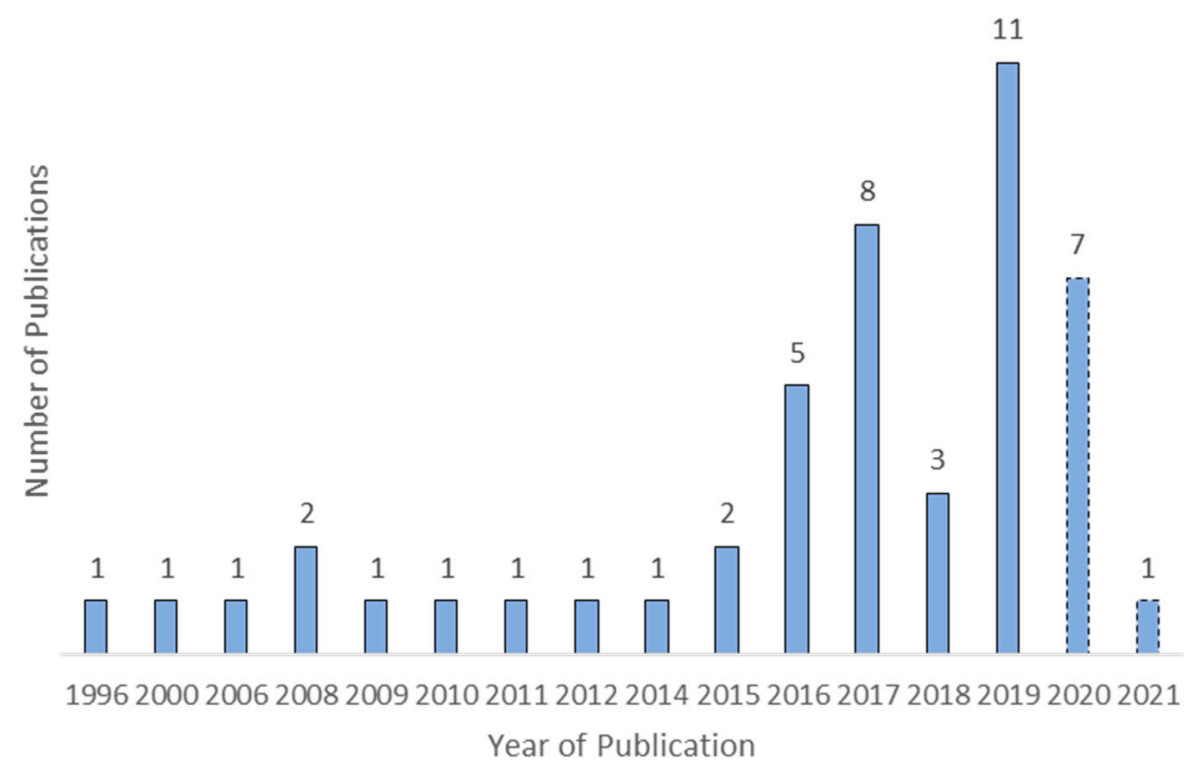

Figure 2. The distribution of papers in year of publication. The years 2020/2021 are not complete as the literature search ended in September 2020.

The ranking of the most cited papers in the citation indexes of SD and the citation network of the WoS Core Collection presented research articles, except the second ranked paper, which is a literature review on consumer attitudes and their clothing disposal behaviour. The most cited paper by Davis et al. [70] was a survey to understand recycling participation in the UK (see Table 3).

\subsubsection{Trends of Research Studies and Topics}

The theories applied in the reviewed articles mainly referred to consumer behaviour models such as the attitude theories and the attitude-behaviour relationships models. Most essential theories were recorded as the theory of reasoned action [71,72] applied to analyse consumer and designer attitudes and behaviours, as well as the theory of planned behaviour [73], investigating the attitude-behaviour gap. Other consumer-related theories referred to the consumer decision-making process, including consumer preference and willingness to buy, sustainable consumption drivers and barriers, as well as consumer values such as the typology of consumer value [74]. Few studies applied sensory evaluation and studied perception, for example, for materials [75] using sensorial scales. Several other theories were used such as the unified theory of acceptance, the use of technology, the source credibility theory, as well as the contamination theory [76-78] and behavioural avoidance of a negative stimulus [79]. Moreover, product storytelling "narrative" and the institutional theory and customer behaviour [80] were discussed. Hence, a diverse range of case studies was seen in several articles [81-88].

The methodologies applied in the reviewed articles were recorded as mainly quantitative methods such as survey in terms of an online questionnaire, using illustration, and the mall intercept method [89]. Qualitative methods applied were mostly interviews in terms of unstructured or expert interviews. Moreover, workshops and experiments were used, such as sensorial experiments, online field experiments, as well as testing. Several studies used two- or three-stage mixed methods [90] such as qualitative open-ended questions and quantitative survey, survey, and experimental study, as well as interview, survey, and semi-Delphi [91] methods. Further, several case studies were found in the articles, as well as several other single-used methodologies. 
Table 3. The most cited papers.

\begin{tabular}{|c|c|c|c|c|}
\hline Rank & Title & Author, Year & Journal & Citations \\
\hline 1 & $\begin{array}{l}\text { Demonstrating the need for the } \\
\text { development of internal research } \\
\text { capacity: Understanding recycling } \\
\text { participation using the Theory of } \\
\text { Planned Behaviour in West } \\
\text { Oxfordshire, UK }\end{array}$ & Davis et al., 2006 & $\begin{array}{l}\text { Resources, } \\
\text { Conservation and } \\
\text { Recycling }\end{array}$ & 63 \\
\hline 2 & $\begin{array}{l}\text { Doing the 'dirty work' of the green } \\
\text { economy: Resource recovery and } \\
\text { migrant labour in the EU }\end{array}$ & Gregson et al., 2016 & $\begin{array}{l}\text { European Urban and } \\
\text { Regional Studies }\end{array}$ & 20 \\
\hline 3 & $\begin{array}{l}\text { Between classification, objectification, } \\
\text { and perception: Processing } \\
\text { secondhand clothing for recycling } \\
\text { and reuse }\end{array}$ & Botticello, 2012 & $\begin{array}{l}\text { Textile-The Journal } \\
\text { of Cloth and Culture }\end{array}$ & 18 \\
\hline 4 & $\begin{array}{l}\text { Consumer attitudes and } \\
\text { communication in circular fashion }\end{array}$ & Vehmas et al., 2018 & $\begin{array}{l}\text { Journal of Fashion } \\
\text { Marketing and } \\
\text { Management }\end{array}$ & 16 \\
\hline 5 & $\begin{array}{l}\text { Fashion interest as a driver for } \\
\text { consumer textile waste management: } \\
\text { Reuse, recycle or disposal }\end{array}$ & Weber et al., 2017 & $\begin{array}{l}\text { International Journal } \\
\text { of Consumer Studies }\end{array}$ & 15 \\
\hline 6 & $\begin{array}{l}\text { Collaborative redesign of used clothes } \\
\text { as a sustainable fashion solution and } \\
\text { potential business opportunity }\end{array}$ & $\begin{array}{l}\text { Janigo and } \mathrm{Wu}, \\
2015\end{array}$ & $\begin{array}{c}\text { Fashion } \\
\text { Practice-The } \\
\text { Journal of Design } \\
\text { Creative Process and } \\
\text { The Fashion Industry }\end{array}$ & 14 \\
\hline 7 & $\begin{array}{l}\text { Turning ocean garbage into } \\
\text { products-Consumers' evaluations of } \\
\text { products made of recycled } \\
\text { ocean plastic }\end{array}$ & Magnier et al., 2019 & $\begin{array}{l}\text { Journal of Cleaner } \\
\text { Production }\end{array}$ & 14 \\
\hline 8 & $\begin{array}{l}\text { Closing the loop: An exploratory } \\
\text { study of reverse ready-made garment } \\
\text { supply chains in Delhi NCR }\end{array}$ & $\begin{array}{l}\text { O'Reilly and } \\
\text { Kumar, } 2016\end{array}$ & $\begin{array}{l}\text { International Journal } \\
\text { of Logistics } \\
\text { Management }\end{array}$ & 12 \\
\hline 9 & $\begin{array}{l}\text { Exploring attitude-behavior gap in } \\
\text { sustainable consumption: } \\
\text { Comparison of recycled and upcycled } \\
\text { fashion products }\end{array}$ & Park and Lin, 2020 & $\begin{array}{l}\text { Journal of Business } \\
\text { Research }\end{array}$ & 12 \\
\hline
\end{tabular}

Furthermore, the research studies of the reviewed articles had a wide geographical range. The countries covered most were the United Kingdom ( 5 times) and United States (4 times), India and Malaysia (3 times), as well as Australia, Italy, Korea, and The Netherlands (2 times). Other countries studied were Brazil, Canada, China, the European Union, Finland, Germany, Hong Kong, Lithuania, Poland, France, Spain, Romania, Slovenia, and Turkey. Some articles carried out international studies, hence selecting several countries.

With reference to the network visualisation of the bibliometric data, Figure 3 shows the relationship of topics and articles related to the perception of RT and CF, presented within 3 clusters.

The 18 items within the 3 clusters-(1) value (red colour), (2) clothing (green colour), and (3) impact (blue colour)-emerged as the following. In cluster (1) (9 items), the main topic refers to value (occurrences: 13). Value mainly referred to consumer added value related to sustainability and the products' symbolic value [46,92-94]. Other value-related mentions were value orientations [95], value for money [96], economic value added to companies [82,85], the fashion index value [97], and poor value appropriation for recycling [87]. Value can be added through a diverse range of strategies (occurrences: 11) and responses (occurrences: 9), including a practical recycling strategy [85], marketing communication strategy [98], strategy of past identity [99], or a collective strategy in terms of the implementation of life cycle assessment (LCA) [79]. Responses related mainly to marketing [99]. Other topics were disposal (occurrences: 7) in terms of clothing disposal behaviour, sample (occurrences: 
7) referring to the study samples, as well as textile (occurrences: 6), landfill (occurrences: 6), reuse (occurrences: 6), and textile waste (occurrences: 5 ). In cluster (2) (5 items), the main topic refers to clothing (occurrences: 10) and the fashion industry (occurrences: 5) in relation to sustainability (occurrences: 8) and awareness (occurrences: 6), as well as research participant (occurrences: 6). Cluster (3) (4 items) presents the main topic impact (occurrences: 12) and refers to the importance (occurrences: 6) and need (occurrences: 6) related to the environment (occurrences: 5). Most studies highlighted the importance of the sustainability concept in the fashion industry [100]. To summarise, the first cluster refers to actions and concrete proposals, the second cluster contains studies regarding awareness, and the third cluster includes programmatic papers comprising the need to discuss the environmental impact.

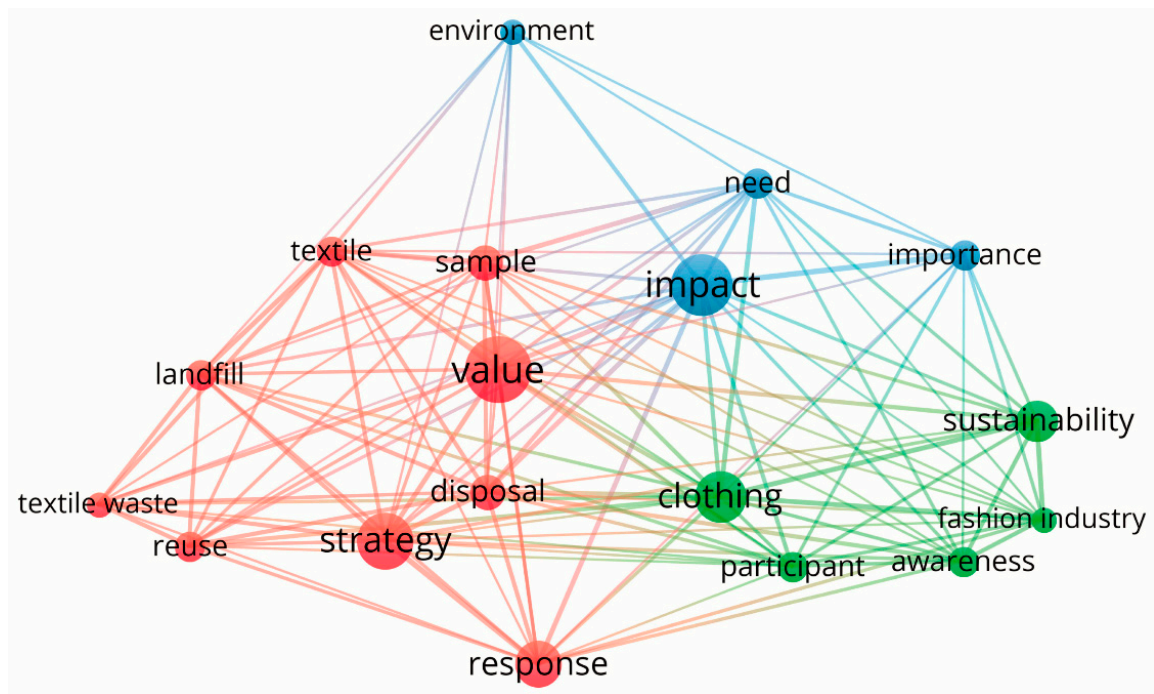

Figure 3. The three clusters of research topics related to the perception of recycled textiles and circular fashion.

In Figure 4, the development of the research articles over time is shown, whereby the articles published in 2013 focused on awareness and environment related to textiles, and the more recent publications shifted to topics focused on value and sustainability with relation to textile waste.

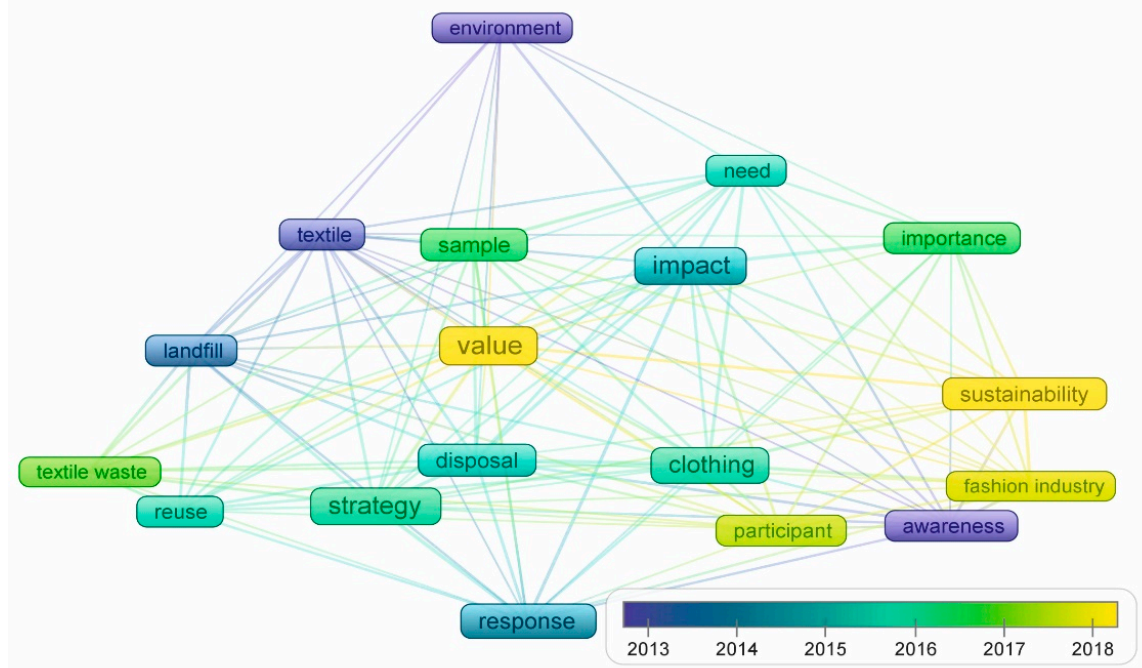

Figure 4. The development of the research articles over time from awareness to value-related topics. 


\section{Results}

The results in the following section are linked to the three topics of awareness, needs, and actions (see Figure 3), and the development towards value-related topics (see Figure 4). This chapter presents the analysis of the 47 articles selected for qualitative synthesis to investigate human perception of RT and CF. An overview of the articles is presented in Appendix A.

The analysis was based on the two major consumer behaviour topics of awareness and attitudes, which are linked to behavioural responses: (1) awareness, in terms of consumer and industry awareness of general clothing sustainability, (1.1) consumer awareness of recycling and disposal, and (1.2) industry awareness of recycling, as well as (2) attitudes and response including perceived values, in terms of (2.1) consumer attitudes, and (2.2) industry attitudes.

\subsection{Awareness of Sustainability}

The awareness of sustainability and perceived added value for consumers and industry is discussed in the following 16 articles. Research refers to consumer awareness of clothing sustainability, sustainable clothing consumption and disposal, as well as industry awareness in terms of designer awareness [101] and manufacturer attitudes related to consumer awareness [102].

Awareness can positively influence sustainable fashion behaviour and consumption. There is a diverse range of sustainable RT materials and CF business models, and consumer perceptions vary accordingly. Some sustainable concepts are perceived as adding value [92]. The studies recognised increasing awareness of sustainability in general [84,92,103], growing trends such as the sharing economy in terms of collaborative consumption [95], and more and more awareness of companies in the fashion industry realising the need for sustainable offers $[88,100]$. Nevertheless, risks and losses were also perceived, as discussed below.

Five study results revealed that awareness of sustainable clothing and consumption is somewhat limited [92,100,104-106]. Other studies [92,107], introducing concepts of sustainability and illustrating fashion retailers' responses to sustainability, found that even though participants showed some sustainable behaviours, the awareness of fashion sustainability was low. However, sustainable concepts that are widely available in the mainstream can stimulate awareness and concern, such as organic food that is now widely available in mainstream supermarkets, highlighting the use of chemicals. Yet, there is a gap in the literature regarding consumer perception of chemicals used in fashion [92]. The results of an international study focused on sustainable clothing consumption suggested that more awareness-raising initiatives for consumers are needed [104].

Similar to the results of Paço et al. [104], a focus groups study in Turkey with Generation Y consumers by Ozturk and Engizek [105] highlighted the lack of awareness as one of the most significant barriers for ethical fashion consumption. Another study in Turkey by Saricam et al. [100] claimed that the awareness level of sustainable fashion consumers is a gap in the literature, and survey results revealed that the level of awareness is low; socio-demographic characteristics showed that the awareness level increased somewhat with level of education and income, specifically with males and participants aged between 24 and 29. Furthermore, the participants perceived the sustainability concept in the fashion industry as limited to the usage of organic materials and recycling [100]. In another study, sustainable consumption was linked to purchasing environmentally friendly, durable, and repairable products [88]. Magnier et al. [96] measured awareness as "awareness of the environmental issue" and "awareness of ocean plastic recycling". There was a high awareness of the environmental issue in terms of good knowledge of the "plastic soup" issue [96].

\subsubsection{Consumer Awareness of Recycling and Disposal}

There have been many reports and media acknowledgements on the textile waste issues in the fashion industry, and retailers are shown to be promoting in-store recycling for unwanted garments. Still, products made from recycled materials are a niche market [92]. Even so, despite consumers 
being conscious of recycling and perceiving it as a sustainability concept of the fashion industry [100], the consumer disposal of fashion has remained a research gap compared to other successful material recycling options such as glass, plastic, and paper [92]. The study in the UK by Ritch [92] found that there was limited awareness of fibre recycling and its sustainable contribution. A study conducted in India by Norris [108] referred to the growing Indian consumer awareness of recycling as an environmentally friendly practice, as well as recycling as an ancient process that is even linked to reincarnation [108]. A quantitative study carried out in Malaysia by Yee et al. [106] focused on the clothing disposal behaviour of young fashionable consumers and showed that it is affected by philanthropic awareness and somewhat by the attitude towards clothing disposal. The authors suggested that these insights could be used by the government and related authorities or organisations to develop strategies accordingly to foster consumer clothing recycling [106]. Moreover, the consumer experience of a collaborative redesign can help to raise awareness of redesigned and sustainable clothing [109].

\subsubsection{Industry Awareness of Recycling}

Some of the reviewed articles discussed the awareness of sustainability in the textile and fashion industry. Baier et al. [88] highlighted the increased awareness of sustainability needs, particularly in the clothing and footwear industry: A case study affiliated to the apparel and sportswear company Adidas AG measured the consumption of Adidas sneakers in terms of sustainable aspects and offerings such as upcycled (ocean plastic) or recycled (post-consumer waste) products. Products made of recycled ocean plastic were also studied by Magnier et al. [96]. Likewise, the review by Rucker [56] emphasised the importance of recycled synthetic fibres in the outdoor and sports apparel industry, describing a case study by Meyer [55] of the sportswear and outdoor clothing company Patagonia and their marketing strategy for fleece products made of recycled plastic bottles. The reviewed case study by Wang and Shen [84] analysed Patagonia's product line.

In contrast to consumer studies, an international survey based in Texas, the USA, by Stark and Cudhea [101] analysed designer awareness of social issues and sustainable design decisions including sustainable attributes such as recycled materials in the interior textile design industry. The questioned designers showed a lack of awareness of evaluative tools through third-party certifications, proving the "sustainability gap" phenomenon between theory and practice as identified by Stieg [101,110]. A study by Testa et al. [83] considered well-known barriers of general innovative management practices, such as low level of knowledge and awareness, in their research to implement LCA among small and medium enterprises (SMEs) as a collective strategy for exploiting recycled wool. Finally, the relationship of consumer awareness and the attitudes of manufacturers in the United States were analysed by Grasso [102] through a questionnaire, including recycling practices, barriers, and strategies, and suggesting marketing strategies in terms of lower prices and co-operative advertising. The author described the pressure towards increased fabric cutting waste recycling, referring to rising landfill costs [102]. Another study in China suggested firm engagement with non-governmental organisations (NGOs) to support consumer adoption of sustainable products [81].

\subsection{Attitudes and Responses to Sustainability}

In social sciences, attitudes toward a behaviour link belief to some attributes in terms of positive or negative perceptions and feelings [73]. Consumer behaviour includes theories based on purchase behaviour or involvement related to values as well as demographics. The reviewed articles addressed sustainable consumer behaviour and attitudes regarding the purchase, use, reuse, recycling, upcycling, and disposal of fashion products and textile waste. Participation in recycling, disposing, or hoarding are clothing post-purchase behaviours [111]. The studies also disclosed perceived advantages and disadvantages, as well as the weight of clothing-specific attributes.

Generally, consumer attitudes are positive toward circular products such as recycled or upcycled goods [112]. However, some studies have shown that consumers may perceive CF products negatively 
in terms of lower perceived quality. The study by Park and Lin [112] assumed that many consumers in Korea have a positive attitude toward sustainable products. Nevertheless, this attitude does not influence green buying behaviour, referring to the green purchase gap. Other factors and the product type influence the intention-behaviour-positive perceived utilitarian values in terms of quality and performance, consumer effectiveness and reduced availability, and economic risk are important for recycled (second-hand) and upcycled fashion products. Consumer effectiveness is a consumer belief that actions can affect the environment [113], whereby respondents perceived that upcycled products have more utilitarian value than recycled products but have high economic risk. In addition, recycled fashion products were found to have more availability risk than upcycled fashion products [112].

\subsubsection{Consumer Attitudes towards Sustainable Purchase Behaviour}

Similarly, several studies presented both positive and negative consumer attitudes towards sustainable behaviour. The international study undertaken by Paço et al. [104] found positive and negative values towards recycling in terms of clothing disposal that included mainly donation and swapping with family and friends, and of clothing reuse in terms of second-hand buying behaviour. The results of the survey showed perceived environmental and economic advantages, such as the prevention of resources and environmental depletion, as well as cost benefits. The participants showed ecological willingness to avoid waste, to help others, and to bring about a good impact on the environment-only $1.55 \%$ of the participants put clothes in the trash [104]. The study of consumers in the UK by Ritch [92] evaluated attitudes within household behaviours influenced by values; for fashion, this included aesthetics, status, and esteem. Sustainability concepts represented by fashion labels such as $M \& S$ child's fleece made from recycled plastic-bottles were perceived as appealing due to added value attributes in terms of novelty and play, especially during the festive period. One respondent supported recycling as a sustainable consumption solution and better than conventional polyester. Ritch [92] found that the practice of sustainability fluctuates and is subject to the availability of information and support. Participants had preferences and confidence in recycling and recycled goods but were less specific and familiar with concepts such as chemical usage and exploitation.

Kamleitner et al. [99] carried out six studies in the USA and Europe. They found that the past identity salience through storytelling and the feeling of specialness resulted in positive consumer response and demand for past identity products such as upcycled products in terms of an upcycled backpack made from an old airbag and recycled products in terms of old recycled plastic, but not for conventional polyester [99]. The study carried out in the Netherlands by Magnier et al. [96] found that participants had a mainly positive general attitude (overall impression in terms of bad/good, unfavourable/favourable, dislike/like, negative/positive) towards textile products made of ocean plastic, including positive expectations of quality, functionality, and attractiveness, as well as low safety and contamination risks. Respondents' purchase intention was higher for the running shoes made of ocean plastic than for the sweater [96].

The study by Moosmayer et al. [81] looked at Chinese consumers and their cosmopolitan values and found that sustainability attitude in terms of "willingness to reward" and firm-NGO engagement positively influenced the adoption of sustainable products made from recycled fibres, but firms' sustainability engagement and attitudes toward firm-NGO engagement were not correlated [81]. Consumers' formed positive perceptions including brand and corporate social responsibility (CSR) attitudes (i.e., appealing, good, favourable, likeable, pleasant) toward CSR practices of sustainable brands (i.e., in-store apparel recycling program) when promoted through the brand's website, but not through news articles [114].

\subsubsection{Consumer Attitudes towards Sustainable Use Behaviour and Consumption}

The study by Ianole-Calin et al. [95] analysed the influence of individualist and collectivist culture values within the sharing economy (SE) in terms of collaborative consumption and found 
that responsibility positively impacted consumers' attitude toward collaborative consumption in Romania and Italy, whereby advice and uniqueness moderately impacted Romanian consumers only. Shrivastava et al. [115] measured consumer attitudes towards CF in terms of usage of online rental clothing platforms as desirable, environmentally sustainable, a trend, and favourable, and found that it influenced the behavioural intention.

A study in the UK by Sung et al. [116] measured attitudes of upcycling in terms of a pleasantness scale and found that the primary perceived benefits were economic and environmental followed by enjoyment, fun, and feel-good reasons in the creation process of upcycling, as well as product personalisation, learning experience, along with recognition and appreciation. Moreover, interventions to scale up upcycling were evaluated as community workshops, upcycling centre, or materials provision service, supported by design experts of companies and NGOs [116]. A study in Korea by Shim et al. [117] studied the attitude of upcycling in families with respect to sustainability, finding positive attitudes for upcycling clothing-consumers also perceived themselves as role-models for the fashion industry. Benefits of recycling were a positive impact on the environment by reducing waste, economic saving, long time wear, as well as emotional satisfaction during and after recycling practice. Moreover, a donation was perceived as good, easy, and exciting; purchasing up-cycled clothing was perceived as "a good thing" and adding value, including quality. On the other hand, participants felt powerless ("have no option") regarding the production of disposable fast fashion. Moreover, upcycling was perceived as costing time, energy, and skills; quality could decrease, and if not done in the right way, it could be a waste [117].

Western travellers in India valued used garments as recycled cultural heritage by reusing local aesthetics and formed perceptions of belonging; upcycled saris were positively perceived as unique and exotic yet familiar [108]. Janigo and $\mathrm{Wu}$ [109] studied collaborative redesign and found consumer uncertainty with co-design, as well as negative attitudes related to time and garment type. However, participants had positive experiences in the ideation stage of the redesign process, including hedonic value and personal style. Furthermore, they were comfortable with used clothing and were interested in utilising a redesign service [109]. Many consumers tend to prefer clothing reuse instead of disposal, but convenience is of utmost importance [118].

\subsubsection{Consumer Attitudes towards Sustainable Post-Purchase Behaviour}

Davis et al. [70] determined the attitudes of UK citizens towards household recycling, including textiles and waste minimisation, finding that participants had strong positive attitudes towards recycling. They were influenced by the need to bury less waste in landfills, and the fact that recycling saves resources and protects the environment. Environmental attitudes toward general waste recycling behaviour such as recycling plastic and other traditional commodities could positively influence clothing disposal behaviour [119]. However, the findings of Hyun-Mee [111] and Zurga et al. [120] are inconsistent with such studies, suggesting no positive relationship between environmental attitudes and clothing disposal behaviour. Likewise, Grasso et al. [121] measured consumer attitudes toward recycling in general in terms of environmental and social responsibility but found no direct relationship with consumer behaviour and purchase of recycled textile products. In another study, the level of fashion interest was analysed as a driver for consumer textile waste management in terms of reuse, recycle, or disposal [97].

Grębosz-Krawczyk and Siuda [98] identified the attitudes of young consumers in Europe toward the concept of the $\mathrm{CE}$ in terms of branded recycling campaigns such as the exchange of old clothes for discount vouchers, finding that consumers in Poland, France, and Spain have a minor engagement but high willingness to participate in such campaigns, as well as a positive perceived brand image. Vehmas et al. [47] found an increased consumer interest towards recycling of textile waste and sustainable solutions such as circular clothing, as well as more visible and concrete information, including environmental impacts of textile production. Multiple communication channels, the shopping experience, and digital services could create additional value for consumers [47]. The study carried 
out in India by O'Reilly and Kumar [87] highlighted the importance of "sense of duty" in attitude formation of an intention to recycle garments. Additional important factors were the availability and accessibility of recycling options, as well as self-efficacy issues [87]. Other positive consumer attitudes towards clothing disposal behaviour referred to charity issues and related to education, knowledge, and understanding of effective disposal methods [106,122].

\subsubsection{Negative Consumer Attitudes}

In the following section, the perceived risks of RT and CF are discussed. Some studies documented no perceived risks, or low risks in terms of expected quality, functionality, and contamination [96]. Other studies reported perceived negative consumer attitudes towards reuse and recycling of fashion and textiles due to cleanliness, contamination, and previous ownership, as well as availability, considering new items as being more durable, and such items being culturally not acceptable and/or associated with poverty $[104,123]$. The quality of recycled materials was perceived as "not as good" but "improving" compared to conventional materials [92] (p. 275)—one participant responded that "polyester just reeks of the 1970s: electric shocks and neon colours!" [92] (p. 276); however, labels can help to improve negative feelings. The international study by Meng and Leary [124] found that consumers from Poland, France, and Spain perceived a T-shirt made from recycled plastic bottles as contaminated and it was received with heightened disgust, whereas a carrying bag was not negatively perceived. The study by Zurga et al. [120] identified negative attitudes toward buying second-hand apparel in Slovenia-consumers perceived inconvenience as there are not enough second-hand shops available, as well as lack of cleanliness perceived by the elder, male respondents, that are unemployed with the highest education levels. Public policy must support both the education of the consumer and the industry [104].

\subsubsection{Worker/Industry Attitudes: Manufacturer, Retailer, Brand, and Designer}

The conceptual paper by Raducanu [103] refers to the environmental awareness and the ecological attitudes of consumers from Central and Eastern Europe, and the new approach of textile "ecoconception" which is bound to the ecology of human resource, the ecology of production, and the ecology of recycling rubbish. With regards to sustainable interior textile design including recycled materials, the study of Stark and Cudhea [101] found that designer attitudes toward sustainable design decisions are only somewhat related to personal commitment and concern for the environment and social responsibility, but mostly to external factors such as client preferences, project requirements, or company management and standards. Norris [94] looked at the variable consumer perceptions within the complex value system of post-consumer clothing fibres in terms of recycled wool. The study focused on the influence of the recycling system and cultural values. These values related to clothing challenges of hygiene and cleanliness-fears of lower quality, dirt, and contagion. The author found through field observations and interviews with manufacturers and brands in Germany, the UK, and Italy that there was uncertainty about value creation, storytelling, and risk perception. Advantages of recycling in terms of in-house recycling were related to increased confidence regarding transparency and traceability, including knowledge of the fibre origin. Chemically recycled fibres can be perceived as more "clean" and culturally acceptable than mechanically recycled fibres. Disadvantages of wool were evaluated by material experts as underutilised and devalued fibre perception [94]. Yu and Lee [125] reviewed the consumer purchase of upcycling and how firms can identify a positive or a negative attitude towards creative consumers and take active or passive actions. Botticello [126] analysed worker perception and values of processed second-hand clothing for recycling and reuse in a UK sorting facility with relation to material qualities and dirtiness in terms of condition, wear, and reusability. Benefits of right sorting are related to the increased brand value of the sorting factory. However, it was noted that reuse and sorting are subjective and context-specific [126]. 


\section{Discussion}

In this section, the results of the SLR are discussed regarding the perception of RT and CF to understand the influence of recycling upon the society, economy, and environment through contextual aspects. The paper concludes with research gaps, future research suggestions, and limitations. According to the previously defined research questions, we discuss the following aspects in detail, corresponding to findings of the reviewed articles.

\subsection{Measures for Consumer and Industry Awareness}

Awareness was measured towards

- Sustainability in general;

- Consumer recycling and disposal;

- Industrial recycling.

The reviewed articles discussed consumer awareness as well as industry awareness in terms of companies, brands, and designers. For example, Patagonia was one of the pioneering companies using recycled polyester [6]. The two case studies by Baier et al. [88] and Wang and Shen [84] analysed the sportswear brands Adidas and Patagonia and their recycled products. Additionally, researchers are interested in industry awareness of recycling in terms of designer awareness. This study proved that the "sustainability gap" also exists among practitioners [101]. Still, manufacturers felt the pressure towards increased recycling practices.

When analysing the awareness towards sustainability, on the one side, it was found that consumers have an increasing awareness of sustainability in general. On the other side, little and complete lack of awareness exists among consumer groups. Awareness was measured in different ways. Awareness was assessed in terms of environmental issues and ocean plastic recycling [96]. Recycling was seen as an ancient process that is even linked to reincarnation [108].

Awareness can influence sustainable fashion consumption. For example, clothing disposal was positively affected by philanthropic awareness [106]. Accordingly, the development of strategies is needed to foster consumer clothing recycling [106], and unique consumer experience can help to raise awareness through, for example, collaborative redesign [109]. Hence, such sustainable fashion models and concepts mentioned in the reviewed articles were, for example, upcycling and collaborative redesign.

The accessibility of products in terms of widely available and mainstream point of sales might stimulate awareness and consumer behaviour, but consumer perception of fashion production processes such as usage of chemicals might still be limited [92]. The sustainability concept in the fashion industry is perceived as limited to the usage of organic materials and recycling [100]. However, there was limited awareness of fibre recycling and its sustainable contribution [92]. For example, Testa et al. [83] studied the implementation of LCA among SMEs as a collective strategy for exploiting recycled wool. Still, more concrete LCA studies are needed to determine the environmental and social impacts.

\subsection{Opportunities and Barriers of Attitudes and Response}

Attitudes included positive and negative consumer and industry (manufacture, retailer, brands) attitudes and were assessed towards

- Sustainable purchase behaviour;

- Sustainable use behaviour and consumption:

- Sharing economy (collaborative consumption: online rental clothing platforms);

- Upcycling community workshop;

- Collaborative redesign and co-design;

- Sustainable post-purchase behaviour. 
There are numerous variables such as consumer demographics or product attributes that influence consumer attitudes towards RT and CF and recycling behaviour. As Park and Lin [112] showed, general consumer attitudes are positive toward circular products, but this might not positively influence green buying behaviour due to other factors, such as perceived values and the product type. For example, running shoes made of ocean plastic received higher purchase intention than a sweater [96]. In collaborative redesign, consumers can be uncertain and may have negative attitudes towards garment-type requirements and time [109], as convenience is crucial [127]. Additionally, consumers can feel powerless [117].

Perceived environmental and economic advantages exist and could be stimulated through additional value attributes in terms of novelty and play, as well as increased familiarity [92]. The positive attitudes towards the creation process of upcycling, such as enjoyment and fun [112], correspond to the findings of happiness in activities by Csikszentmihalyi and Wong [45]. Similarly, Kamleitner et al. [99] found that past identity salience through storytelling results in positive consumer response. Moroever, multiple communication channels, the shopping experience, and digital services could create additional value for consumers [47].

Industry attitudes were highly influenced by external factors such as client preferences [101]. Nevertheless, the benefits of recycling were perceived, such as the expertise in sorting that can increase the brand value [126]. In one study, it was suggested that chemically recycled fibres could be perceived as more "clean" and culturally acceptable than mechanically recycled fibres [94].

\subsection{Contexts}

Various disciplines and studies were used to understand how RT and CF impact society. As seen from the journal selection of the articles reviewed in Section 2.2.1, research related to social sciences and humanities in terms of consumer behaviour, and subjects such as sustainable development and consumption, as well as sustainable products and services. Fields included marketing and branding, business, economy and waste management, product design, as well as fashion and culture. As seen in Section 3.1, the growing trend of the CE concept created awareness among consumers and industry towards sustainable developments in terms of textile waste recycling. This movement could also involve firm engagement with NGOs to support consumer adoption of sustainable products [81]. For example, the registered UK charity WRAP works with governments, businesses, and communities to accelerate the move to a sustainable, resource-efficient economy. Global politics are keenly promoting the CE through consortia such as the Organisation for Economic Co-operation and Development (OECD) and United Nations Environment Programme (UNEP), as well as through reports and events [69]. For example, the UN environment programme presents a circularity platform (www.buildingcircularity.org, 2020), focusing on the plastics, textiles, and electronics sectors. According to the European Urban Knowledge Network (EUKN) [128], the country leaders of CE policies in Europe are Denmark, Germany, the Netherlands, and the UK [69]; in Asia, early pioneers are Japan and China [69]. Several studies targeted the UK, and the survey carried out in the UK by Davis et al. [70] was the most cited paper. The UK has increased interest to implement the CE with reference to its heritage and economy-besides having the highest textile consumption rate in the EU [2], the UK is among the top 10 EU textile and clothing producers, with an economic value of GBP 9 billion [14]. According to the perspective of Hawley [16], the textile recycling process is a global system. Increased textile waste globally makes it necessary to implement disposal strategies and cross-cultural research. For instance, Ianole-Calin et al. [95] found different consumer attitudes toward collaborative consumption in Romania and Italy.

Several of the reviewed articles used case studies [81-88] and had various specific contexts to study consumer and industry perceptions in terms of textile manufacturers, brands and retailers, and designers, considering geographies, cultures, specific situations, as well as garment types. This more restricted context makes it difficult to generalise these results. For example, Baier et al. [88] focused on the perspective in an apparel and sportswear context. Furthermore, responses to RT and CF were 
discussed within the contexts of circular business models such as the CE [60,61], as well as sustainable design strategies such as "design for cyclability" [28]. Researchers in the sustainability field have established ground-breaking concepts for sustainable development and waste management, such as the "cradle-to-cradle" philosophy by architect McDonough, as well as the work of process engineer Braungart [62], who with regards to the notion of "why being 'less bad' is no good" states the limited benefits of merely reducing, recycling, or downcycling. In one article, consumers had similar attitudes towards the quality of recycled materials, perceived as "not as good" but "improving" compared to conventional materials [92] (p. 275). Negative perceptions towards RT were linked to contamination theories. In social sciences, de Coverly et al. [129] discussed "the social avoidance of waste" and stated that "waste is socially sensitive". Derksen and Gartrell [130] studied the social context of recycling and found that besides concern and attitudes towards the environment, people need access to a structured recycling program to adopt pro-environmental behaviours in terms of recycling. Several of the reviewed articles considered accessibility and convenience as dominant factors. For example, availability and accessibility of recycling options were important factors to facilitate attitude formation of an intention to recycle garments [87], with widely available and mainstream point of sales stimulating awareness of recycled products [92]. Recycling exists far back in history and has often emerged in a new way or trend, for instance, upcycled saris that were used then and now in different contexts, with reference to "reincarnation" and creating cultural meaning [108].

\subsection{Research Agenda}

Most of the reviewed studies tried to understand the gaps between perception and behaviour in terms of the attitude-behaviour gap, referring to the theory of reasoned action [71,72] and the theory of planned behaviour [73]. Future research directions in terms of research topics and questions are outlined in the following section. The gaps between existing models and the development of new recycling models that are considering the consumption's context and culture, the technical limitations, and the economic profitability should be taken into account by diverse research disciplines. Regarding the variance of consumer perceptions, experimental consumer studies such as workshops should be carried out, for example, to identify how consumers see their wardrobe in terms of their awareness and knowledge about recycled fashion and the destiny of clothes after use. Storytelling is another method to create awareness that has been proofed effective in some studies. One study showed uncertainty of manufacturers regarding its usage. Companies experience fear of greenwashing and lack of authenticity and these findings could be further addressed. As stated in the introduction, the definition of terms is essential.

\section{Conclusions, Limitations, and Implications}

This manuscript presents the state of the art of human perceptions regarding RT and CF. The SLR shows that there has been variation in understanding of consumer and industry awareness towards sustainability. Some industry sections have been found to be more aware and realising the need for sustainability, while others such as designers need to improve. Consumer awareness of sustainability was found to be influenced by various factors such as socio-demographic characteristics. Although there were fundamental similarities, there were also differences in the perceptions, motives, and behaviours of consumers within customer groups. The consumer disposal of fashion was noticed as being a research gap compared to other successful material recycling options. The variation and complexity in perception and purchasing behaviour of RT and CF was observed in various studies on the basis of consumers' attitude and response. This study found that a significant proportion of consumers from different countries have a basic understanding of sustainable products, but there have been differences in consumers' attitudes towards sustainable purchase, use, consumption, and post-purchase behaviour. There have been diverse and even opposite results concerning the relationships between RT and CF and their perceived product attributes in terms of quality and functionality, as well as social-cultural factors. Manufacturers' and brands' perceived values of RT were observed to be influenced by different 
factors on the basis of the recycling system and cultural values, while designer attitudes towards sustainability were observed to be influenced by external factors. Our qualitative analysis of the literature review showed that most of the reviewed articles focused on case studies addressing specific contexts. This is the reason why any attempts to transfer the findings from one context to another might be difficult, and no general rules related to the implementation of sustainability paths can be applied in every context.

Therefore, main clusters of research topics and their development over time are identified, and the analysis of the results lead to a new research agenda and vision of RT and CF. On the basis of these findings, we can provide a number of implications according to the identified clusters which require further research and policy actions, as well as professional management: "need to discuss the environmental impact", "studies regarding awareness", and "actions and concrete proposals", as well as "value", and "sustainability of textile waste". These clusters could serve as a starting point to develop future research and a vision for sustainable and circular practices, as well as to help policymakers and practitioners to further engage in solutions for a sustainable textile and clothing industry. Textile leaders could include these implications for sustainable and circular practices to facilitate decision-making processes.

Nevertheless, this SLR has limitations regarding the restricted use of two databases and its exclusion of grey literature. Furthermore, the focus of this manuscript was constrained to two main consumer behaviour topics, excluding other areas which could be reviewed in further research. Nevertheless, this study presents an important overview of the available literature in the field of human perceptions of RT materials and CF practices in the textile and clothing industry, including a descriptive analysis of the paper distribution in years, the most cited papers, as well as research trends and topics.

The following implications are suggested on the basis of the clusters:

1. Need to discuss the environmental impact:

- Exact share and rates of mechanical and chemical RT materials and CF practices [18].

- Global and local impact of RT materials and CF practices on the environment [8] and marine ecosystems [9].

- Concrete LCA studies to determine the environmental and social impacts of RT and CF [7].

Estimations are complex and there is still uncertainty of exact numbers regarding the size and the impact of RT and CF [18]; similarly, there are contrary opinions and results that require more studies.

2. Studies regarding awareness:

- Analysis of the awareness towards production processes or the acceptance of advances in technical developments [92].

- Perception of mechanically and chemically recycled textiles, related to cleanliness and cultural acceptance [94], and to create cultural meaning [108].

- Investigation of the awareness of the industry [101,126].

There is a diverse range of sustainable RT materials and CF business models, and consumer perceptions vary accordingly. However, the focus of the reviewed studies was on consumer awareness of RT products and CF services. Awareness of production and technologies remains a gap. Furthermore, awareness is as a major consumer behaviour topic, and few studies have targeted industry awareness. The review identifies diverse levels of awareness and both positive and negative attitudes towards RT and CF. 
3. Actions and concrete proposals:

- To identify the past, present, and future "identity of recycled plastics" [131].

- The acknowledgement of a textile recycling global system [16] must not undermine the local values and approaches to recycling.

- Identification of perceived risks in terms of expected quality, functionality, and contamination, as well as greenwashing and lack of authenticity can help companies to make a better decision [94].

- To create new knowledge in terms of sensory perception, including the haptics of RT materials and CF products - experiential material characterisation [75], and the definition of ethnographic "fashion journeys" of recycled textile materials such as polyester [132].

In future research, the recycling of specific textile materials could be considered, including emerging trends in terms of bio-based waste such as bioplastics [133].

Author Contributions: Conceptualization, M.M.W. and T.H.; methodology M.M.W.; software, M.M.W.; validation, M.M.W. and T.H.; formal analysis, M.M.W.; investigation, M.M.W.; data curation, M.M.W.; writing-original draft preparation, M.M.W.; writing-review and editing, M.M.W. and T.H.; supervision, T.H. All authors have read and agreed to the published version of the manuscript.

Funding: This research was funded by the Creative Industries Clusters Programme managed by the Arts and Humanities Research Council as part of the Industrial Strategy, under grant no. AH/S002804/1.

Acknowledgments: This research is part of the Business of Fashion, Textiles and Technology Partnership Collaborative R\&D Partnership (BFTT), Challenge 5: Circular Materials. The authors are grateful for the partnership with the University of the Arts London (UAL) and would like to acknowledge Kate Goldsworthy and Rosie Hornbuckle.

Conflicts of Interest: The authors declare no conflict of interest. 


\section{Appendix A}

\begin{tabular}{|c|c|c|c|c|}
\hline & Title Articles & Author & Year & Journal \\
\hline 1 & $\begin{array}{l}\text { The drivers of sustainable apparel and sportswear } \\
\text { consumption: A segmented kano perspective }\end{array}$ & Baier et al. & 2020 & Sustainability \\
\hline 2 & $\begin{array}{l}\text { Between classification, objectification, and perception: } \\
\text { Processing secondhand clothing for recycling and reuse }\end{array}$ & Botticello & 2012 & $\begin{array}{l}\text { Textile-The Journal } \\
\text { of Cloth and Culture }\end{array}$ \\
\hline 3 & $\begin{array}{c}\text { Sincerity or ploy? An investigation of corporate social } \\
\text { responsibility campaigns }\end{array}$ & Childs et al. & 2019 & $\begin{array}{l}\text { Journal of Product } \\
\text { and Brand } \\
\text { Management }\end{array}$ \\
\hline 4 & $\begin{array}{l}\text { Waste management system in the clothing industry in } \\
\text { Santa Catarina State Brazil: An initial overview }\end{array}$ & Correia et al. & 2018 & $\begin{array}{l}\text { Management of } \\
\text { Environmental } \\
\text { Quality }\end{array}$ \\
\hline 5 & $\begin{array}{c}\text { Demonstrating the need for the development of internal } \\
\text { research capacity: Understanding recycling participation } \\
\text { using the Theory of Planned Behaviour in West } \\
\text { Oxfordshire, UK }\end{array}$ & Davis et al. & 2006 & $\begin{array}{l}\text { Resources, } \\
\text { Conservation and } \\
\text { Recycling }\end{array}$ \\
\hline 6 & $\begin{array}{l}\text { Investigation of current state of pre-consumer textile } \\
\text { waste generated at Lithuanian enterprises }\end{array}$ & Dobilaite et al. & 2017 & $\begin{array}{l}\text { International Journal } \\
\text { of Clothing Science } \\
\text { and Technology }\end{array}$ \\
\hline 7 & Recycling fabric waste-The challenge industry & Grasso & 1996 & $\begin{array}{l}\text { Journal of The Textile } \\
\text { Institute }\end{array}$ \\
\hline 8 & Consumer behavior toward recycled textile products & Grasso et al. & 2000 & $\begin{array}{l}\text { Journal of The Textile } \\
\text { Institute }\end{array}$ \\
\hline 9 & $\begin{array}{l}\text { Attitudes of young European consumers toward } \\
\text { recycling campaigns of textile companies }\end{array}$ & $\begin{array}{l}\text { Grębosz-Krawczyk } \\
\text { and Siuda }\end{array}$ & 2019 & $\begin{array}{c}\text { Autex Research } \\
\text { Journal }\end{array}$ \\
\hline 10 & $\begin{array}{l}\text { Doing the 'dirty work' of the green economy: Resource } \\
\text { recovery and migrant labour in the EU }\end{array}$ & Gregson et al. & 2016 & $\begin{array}{l}\text { European Urban and } \\
\text { Regional Studies }\end{array}$ \\
\hline 11 & $\begin{array}{l}\text { Towards sustainable clothing disposition: Exploring the } \\
\text { consumer choice to use trash as a disposal option }\end{array}$ & Norum & 2017 & Sustainability \\
\hline 12 & $\begin{array}{c}\text { Sustainable product-service systems for clothing: } \\
\text { Exploring consumer perceptions of consumption } \\
\text { alternatives in Finland }\end{array}$ & Armstrong et al. & 2015 & $\begin{array}{l}\text { Journal of Cleaner } \\
\quad \text { Production }\end{array}$ \\
\hline 13 & $\begin{array}{l}\text { A cross-cultural analysis of how individualism and } \\
\text { collectivism impact collaborative consumption }\end{array}$ & Ianole-Calin et al. & 2020 & $\begin{array}{l}\text { Resources } \\
\text { Conservation and } \\
\text { Recycling }\end{array}$ \\
\hline
\end{tabular}




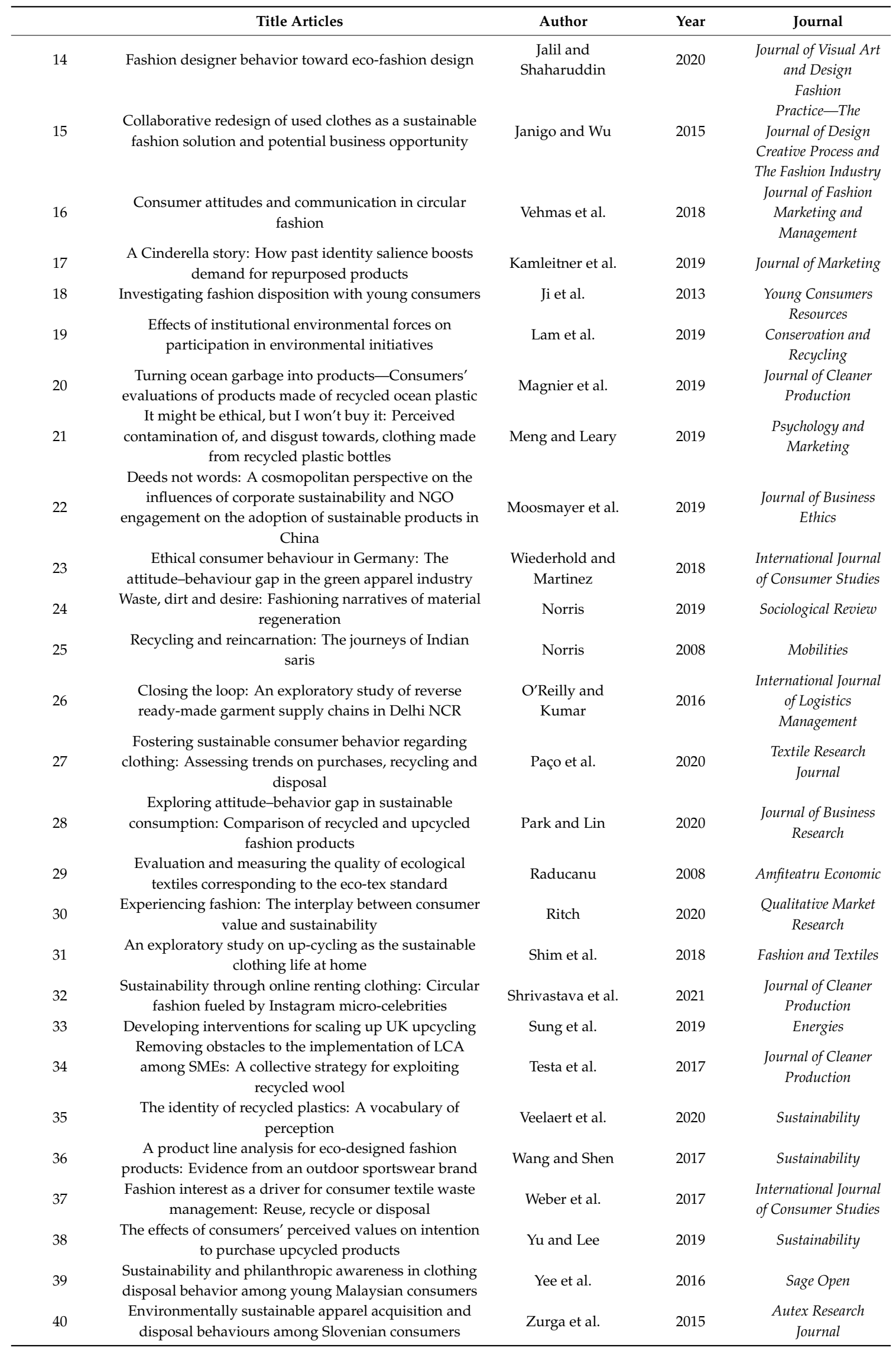




\begin{tabular}{|c|c|c|c|c|}
\hline & Title Articles & Author & Year & Journal \\
\hline \multicolumn{5}{|c|}{ Proceeding Articles } \\
\hline 41 & $\begin{array}{l}\text { An exploratory study on consumers attitudes towards } \\
\text { ethical fashion consumption: Motivators and barriers }\end{array}$ & $\begin{array}{l}\text { Ozturk and } \\
\text { Engizek }\end{array}$ & 2017 & $\begin{array}{c}\text { Global and National } \\
\text { Business Theories } \\
\text { and Practice: } \\
\text { Bridging the Past } \\
\text { with the Future }\end{array}$ \\
\hline 42 & $\begin{array}{c}\text { Towards a typology of waste in fashion practice: An } \\
\text { Australian perspective }\end{array}$ & Payne and Binotto & 2017 & $\begin{array}{c}\text { Product Lifetimes } \\
\text { and The } \\
\text { Environment (Plate) } \\
\text { 17th World Textile }\end{array}$ \\
\hline 43 & $\begin{array}{l}\text { Determination of consumer awareness about sustainable } \\
\text { fashion }\end{array}$ & Saricam et al. & 2017 & $\begin{array}{l}\text { Conference Autex } \\
\text { 2017-Shaping the } \\
\text { Future of Textiles }\end{array}$ \\
\hline 44 & $\begin{array}{c}\text { The human side of the triangle: Using green textile } \\
\text { standards to address social responsibility }\end{array}$ & Stark and Cudhea & 2010 & $\begin{array}{c}\text { Eco-Architecture III: } \\
\text { Harmonisation } \\
\text { between Architecture } \\
\text { and Nature }\end{array}$ \\
\hline \multicolumn{5}{|c|}{ Books } \\
\hline 45 & Chapter $12-$ Textile waste & Bartl et al. & 2011 & Waste \\
\hline 46 & 8-Sustainable synthetic fibre production & & 2017 & $\begin{array}{l}\text { Sustainable Fibres } \\
\text { and Textiles }\end{array}$ \\
\hline 47 & 9-Consumer perceptions of recycled textile fibers & Rucker & 2009 & $\begin{array}{c}\text { Sustainable textiles: } \\
\text { Life cycle and } \\
\text { Environmental } \\
\text { Impact }\end{array}$ \\
\hline
\end{tabular}

\section{References}

1. WRAP. Valuing Our Clothes: The Cost of UK Fashion. 2017. Available online: https: //www.wrap.org.uk/sites/files/wrap/valuing-our-clothes-the-cost-of-uk-fashion_WRAP.pdf?_ga=2. 86011480.1701529797.1581356684-697904570.1581241658 (accessed on 15 November 2019).

2. Watson, D.; Aare, A.K.; Steffen, T.; Petersen, C.D. Used Textile Collection in EUROPEAN Cities: Study Commissioned by Rijkswaterstaat under the European Clothing Action Plan (ECAP). 2018. Available online: https://www.afvalcirculair.nl/onderwerpen/linkportaal/publicaties/downloads/used-textile/ (accessed on 15 November 2019).

3. Statista. Global Fiber Consumption Distribution by Fiber Type 2019. 2019. Available online: https://www.statista.com/statistics/741296/world-fiber-consumption-distribution-by-fiber-type/ (accessed on 13 June 2020).

4. Textile Exchange. Preferred Fiber and Materials Market Report. 2019. Available online: https://store.textileexchange.org/wp-content/uploads/woocommerce_uploads/2019/11/Textile-Exchange_ Preferred-Fiber-Material-Market-Report_2019.pdf (accessed on 13 June 2020).

5. Udale, J. Basics Fashion Design 02: Textiles and Fashion; Ava Series; Bloomsbury Academic: London, UK, 2008; ISBN 9782940373642.

6. Patagonia Inc. Recycled Polyester. 2020. Available online: https://www.patagonia.com/our-footprint/ recycled-polyester.html (accessed on 20 March 2020).

7. Sandin, G.; Peters, G.M. Environmental impact of textile reuse and recycling-A review. J. Clean. Prod. 2018, 184, 353-365. [CrossRef]

8. Garvert, U. A Comparative Study of Recycling in the European and Brazilian Textile Industry. Master's Thesis, Sao Paulo School of Business Administration, Sao Paulo, Brazil, 2017.

9. Ellen MacArthur Foundation. The New Plastics Economy. Rethinking the Future of Plastics. 2016. Available online: https://www.ellenmacarthurfoundation.org/assets/downloads/The-New-Plastics-EconomyRethinking-the-Future-of-Plastics.pdf (accessed on 14 November 2019).

10. The Fair Trade Advocacy Office. MEP Letter in Support of Strategy. 2020. Available online: http: //bit.ly/TextilesEU (accessed on 21 June 2020).

11. Prata, J.C.; Silva, A.L.P.; Walker, T.R.; Duarte, A.C.; Rocha-Santos, T. COVID-19 Pandemic repercussions on the use and management of plastics. Environ. Sci. Technol. 2020, 54, 7760-7765. [CrossRef] [PubMed]

12. Edelkoort, L. Talking Textiles 1. Available online: http://www.edelkoort.com/ (accessed on 15 October 2020). 
13. Hole, G.; Hole, A.S. Recycling as the way to greener production: A mini review. J. Clean. Prod. 2019, 212, 910-915. [CrossRef]

14. EURATEX. Circular Textiles: Prospering in the Circular Economy. 2020. Available online: https: //euratex.eu/wp-content/uploads/EURATEX-Prospering-in-the-Circular-Economy-2020.pdf (accessed on 15 October 2020).

15. Claudio, L. Waste couture: Environmental impact of the clothing industry. Environ. Health Perspect. 2007, 115, A449-A454. [CrossRef]

16. Hawley, J.M. 8-Understanding and improving textile recycling: A systems perspective. In Sustainable Textiles; Blackburn, R.S., Ed.; Woodhead Publishing Series in Textiles; Woodhead Publishing: Cambridge, UK, 2009; pp. 179-199. ISBN 978-1-84569-453-1.

17. Wang, Y.; Hawley, J.M. Textile recycling: A system perspective. Recycl. Text. 2006, 7-24. [CrossRef]

18. Ellen MacArthur Foundation. A New Textiles Economy: Redesigning Fashion's Future. 2017. Available online: https://www.ellenmacarthurfoundation.org/publications/a-new-textiles-economyredesigning-fashions-future (accessed on 14 November 2019).

19. WRAP. Clothing. 2020. Available online: https://www.wrap.org.uk/content/clothing-waste-prevention (accessed on 15 November 2019).

20. Peters, G.M.; Sandin, G.; Spak, B. Environmental prospects for mixed textile recycling in Sweden. ACS Sustain. Chem. Eng. 2019, 7, 11682-11690. [CrossRef]

21. Carney Almroth, B.M.; Åström, L.; Roslund, S.; Petersson, H.; Johansson, M.; Persson, N.-K. Quantifying shedding of synthetic fibers from textiles; a source of microplastics released into the environment. Environ. Sci. Pollut. Res. 2018, 25, 1191-1199. [CrossRef]

22. Sanchez-Vidal, A.; Thompson, R.C.; Canals, M.; de Haan, W.P. The imprint of microfibres in southern European deep seas. PLoS ONE 2018, 13, e0207033. [CrossRef]

23. EEB. Keeping It Clean: How to Protect the Circular Economy from Hazardous Substances. 2017. Available online: https://mk0eeborgicuypctuf7e.kinstacdn.com/wp-content/uploads/2019/05/Keepingit-clean_How-to-protect-the-circular-economy-from-hazardous-substances-2017-3.pdf (accessed on 2 December 2020).

24. Interreg Central Europe. Strategic Agenda on Textile Waste Management and Recycling. Available online: https://www.interreg-central.eu/Content.Node/Stategic-Agenda.pdf (accessed on 15 October 2020).

25. The European parliament and the council of the European union. Directive (EU) 2018/851 of the European parliament and of the council. Off. J. Eur. Union 2018. Available online: https://eur-lex.europa.eu/eli/dir/ 2018/851/oj (accessed on 15 October 2020).

26. European Comission Directive 2008/98/EC on Waste (Waste Framework Directive). Available online: https://ec.europa.eu/environment/waste/framework/ (accessed on 15 October 2020).

27. Textile Exchange. Preferred Recycled Synthetics. Available online: https://textileexchange.org/learningcenter/preferred-recycled-synthetics/ (accessed on 13 February 2020).

28. Roos, S.; Sandin, G.; Peters, G.; Spak, B.; Bour, L.S.; Perzon, E.; Jönsson, C. White Paper on Textile Recycling; Mistra Future Fashion report; RISE IVF AB: Mölndal, Sweden, 2019; ISBN 978-91-89049-46-8.

29. Gray, S.; WRAP. Mapping Clothing Impacts in Europe: The Environmental Cost. 2017. Available online: http: //www.ecap.eu.com/wp-content/uploads/2018/07/Mapping-clothing-impacts-in-Europe.pdf (accessed on 13 February 2020).

30. Filho, W.L.; Ellams, D.; Han, S.; Tyler, D.; Boiten, V.J.; Paço, A.; Moora, H.; Balogun, A.-L. A review of the socio-economic advantages of textile recycling. J. Clean. Prod. 2019, 218, 10-20. [CrossRef]

31. Politowicz, K. Design Lifetimes: A Manifesto for Strategic Change; University of the Arts London: London, UK, 2013.

32. Clair, K.S. The Golden Thread: How Fabric Changed History; John Murray: London, UK, 2018.

33. Rucker, M.; Haise, C. Consumer perceptions of recycled textile fibers. In Proceedings of the First International Symposium on Fiber Recycling, Kyoto, Japan, 20-21 June 2007.

34. McIntyre, J.E. Synthetic Fibres: Nylon, Polyester, Acrylic, Polyolefin; Woodhead Publishing: Cambridge, UK, 2004.

35. Senthil Kumar, P.; Janet Joshiba, G. Properties of recycled polyester. In Recycled Polyester: Manufacturing, Properties, Test Methods, and Identification; Muthu, S.S., Ed.; Springer: Singapore, 2020; pp. 1-14. ISBN 978-981-32-9559-9. 
36. Qin, Y.; Qu, M.; Kaschta, J.; Allen, V.; Schubert, D.W. Studies on recycled polyester. In Recycled Polyester: Manufacturing, Properties, Test Methods, and Identification; Muthu, S.S., Ed.; Springer: Singapore, 2020; pp. $29-67$. ISBN 978-981-32-9559-9.

37. Maegan, Z.W.; Ruoh-Nan, Y. An exploratory study of the decision processes of fast versus slow fashion consumers. J. Fash. Mark. Manag. Int. J. 2013, 17, 141-159. [CrossRef]

38. WRAP. Clothing Longevity and Measuring Active Use. 2013. Available online: https://www.wrap.org.uk/ sites/files/wrap/Clothing-longevity-report.pdf (accessed on 15 October 2020).

39. WRAP. Economic and Financial Sustainability Assessment of f2f Recycling. 2017. Available online: https://www.wrap.org.uk/sites/files/wrap/Fibre_to_Fibre_report.pdf (accessed on 15 October 2020).

40. Cobb, K.; Orzada, B. Coming to our senses: The 21st century tactile. In Proceedings of the International Textile and Apparel Association (ITAA) Annual Conference Proceedings, Cleveland, OH, USA, 5-9 November 2018; p. 117.

41. Albers, A. Handweaving Today: Textile Work at Black Mountain College. Available online: http://www. albersfoundation.org/teaching/anni-albers/texts/ (accessed on 15 October 2020).

42. Healy, C. "Through one's own fingertips"? Haptic perception in the art and thinking of Josef and Anni Albers. J. Humanit. Arts 2016, 2, 1-20.

43. Wagner, M.M. Study of consumer expectation and perception on ethical fashion brands and their relationship with textile parameters by using Kansai and LCA approaches. Ph.D. Thesis, Université de Lille 1, Lille, France, 2019.

44. Kotler, P.; Armstrong, G. Principles of Marketing, 3rd ed.; Pearson Prentice Hall: Saddle River, NJ, USA, 2010.

45. Csikszentmihalyi, M.; Wong, M.M.-H. The situational and personal correlates of happiness: A cross-national comparison. In Flow and the Foundations of Positive Psychology: The Collected Works of Mihaly Csikszentmihalyi; Springer: Dordrecht, The Netherlands, 2014; pp. 69-88. ISBN 978-94-017-9088-8.

46. Nicolao, L.; Irwin, J.R.; Goodman, J.K. Happiness for sale: Do experiential purchases make consumers happier than material purchases? J. Consum. Res. 2009, 36, 188-198. [CrossRef]

47. Vehmas, K.; Raudaskoski, A.; Heikkilae, P.; Harlin, A.; Mensonen, A. Consumer attitudes and communication in circular fashion. J. Fash. Mark. Manag. 2018, 22, 286-300. [CrossRef]

48. Lundblad, L.; Davies, I.A. The values and motivations behind sustainable fashion consumption. J. Consum. Behav. 2016, 15, 149-162. [CrossRef]

49. Shen, B. Sustainable fashion supply chain: Lessons from H\&M. Sustainability 2014, 6, 6236-6249. [CrossRef]

50. Goworek, H.; Hiller, A.; Fisher, T.; Cooper, T.; Woodward, S. Consumers' attitudes towards sustainable fashion, clothing usage and disposal. In Sustainability in Fashion and Textiles: Values, Design, Production and Consumption; Greenleaf: Sheffield, UK, 2013.

51. Pookulangara, S.; Shephard, A. Slow fashion movement: Understanding consumer perceptions-An exploratory study. J. Retail. Consum. Serv. 2013, 20, 200-206. [CrossRef]

52. Shen, B.; Wang, Y.; Lo, C.K.Y.; Shum, M. The impact of ethical fashion on consumer purchase behavior. J. Fash. Mark. Manag. Int. J. 2012, 16, 234-245. [CrossRef]

53. Hatch, K.L.; Roberts, J.A. Use of intrinsic and extrinsic cues to assess textile product quality. J. Consum. Stud. Home Econ. 1985, 9, 341-357. [CrossRef]

54. Joergens, C. Ethical fashion: Myth or future trend? J. Fash. Mark. Manag. Int. J. 2006, 10, 360-371. [CrossRef]

55. Meyer, A. What's in it for the customers? Successfully marketing green clothes. Bus. Strategy Environ. 2001, 10, 317-330. [CrossRef]

56. Rucker, M. Consumer perceptions of recycled textile fibers. In Sustainable Textiles Life Cycle and Environmental Impact; Woodhead Publishing: Cambridge, UK, 2009; ISBN 9781845694531.

57. Strähle, J.; Gräff, C. The role of social media for a sustainable consumption. In Green Fashion Retail; Strähle, J., Ed.; Springer: Singapore, 2017.

58. Forsythe, S.M.; Thomas, J.B. Natural, synthetic, and blended fiber contents: An investigation of consumer preferences and perceptions. Cloth. Text. Res. J. 1989, 7, 60-64. [CrossRef]

59. Lorek, S.; Lucas, R. Towards Sustainable Market Strategies: A Case Study on Eco Textiles and Green Power; Wuppertal Institute for Climate, Environment and Energy: Wuppertal, Germany, 2003.

60. Homrich, A.S.; Galvão, G.; Abadia, L.G.; Carvalho, M.M. The circular economy umbrella: Trends and gaps on integrating pathways. J. Clean. Prod. 2018, 175, 525-543. [CrossRef] 
61. Jia, F.; Yin, S.; Chen, L.; Chen, X. The circular economy in the textile and apparel industry: A systematic literature review. J. Clean. Prod. 2020, 259, 120728. [CrossRef]

62. McDonough, W.; Braungart, M. Cradle to Cradle: Remaking the Way We Make Things; Farrar, Straus and Giroux: New York, NY, USA, 2010; ISBN 9781429973847.

63. Lemille, A. For a True Circular Economy, We Must Redefine Waste. Available online: https://www.weforum. org/agenda/2019/11/build-circular-economy-stop-recycling/ (accessed on 13 October 2020).

64. Thorisdottir, T.S.; Johannsdottir, L. Sustainability within fashion business models: A systematic literature review. Sustainability 2019, 11, 2233. [CrossRef]

65. Arksey, H.; O'Malley, L. Scoping studies: Towards a methodological framework. Int. J. Soc. Res. Methodol. 2005, 8, 19-32. [CrossRef]

66. Moher, D.; Shamseer, L.; Clarke, M.; Ghersi, D.; Liberati, A.; Petticrew, M.; Shekelle, P.; Stewart, L.A.; Group, P.-P. Preferred reporting items for systematic review and meta-analysis protocols (PRISMA-P) 2015 statement. Syst. Rev. 2015, 4, 1. [CrossRef]

67. do Adro, F.J.N.; Leitão, J.C.C. Leadership and organizational innovation in the third sector: A systematic literature review. Int. J. Innov. Stud. 2020, 4, 51-67. [CrossRef]

68. van Eck, N.J.; Waltman, L. Software survey: VOSviewer, a computer program for bibliometric mapping. Scientometrics 2010, 84, 523-538. [CrossRef]

69. Reike, D.; Vermeulen, W.J.V.; Witjes, S. The circular economy: New or refurbished as CE 3.0?-Exploring controversies in the conceptualization of the circular economy through a focus on history and resource value retention options. Resour. Conserv. Recycl. 2018, 135, 246-264. [CrossRef]

70. Davis, G.; Phillips, P.S.; Read, A.D.; Iida, Y. Demonstrating the need for the development of internal research capacity: Understanding recycling participation using the Theory of Planned Behaviour in West Oxfordshire, UK. Resour. Conserv. Recycl. 2006, 46, 115-127. [CrossRef]

71. Ajzen, I.; Fishbein, M. Understanding Attitudes and Predicting Social Behavior; Prentice-Hall: Englewood Cliffs, NJ, USA, 1980; ISBN1 0139364358. ISBN2 9780139364358.

72. Fishbein, M.; Ajzen, I. Belief, Attitude, Intention and Behaviour: An Introduction to Theory and Research; Addison-Wesley: Reading, MA, USA, 1975.

73. Ajzen, I. The theory of planned behavior. Organ. Behav. Hum. Decis. Process. 1991, 50, 179-211. [CrossRef]

74. Holbrook, M.B. Introduction to consumer value. In Consumer Value a Framework for Analysis and Research; Holbrook, M.B., Ed.; Routledge: London, UK, 1999; pp. 1-29.

75. Veelaert, L.; Du Bois, E.; Moons, I.; Karana, E. Experiential characterization of materials in product design: A literature review. Mater. Des. 2020, 190, 108543. [CrossRef]

76. Morales, A.C.; Dahl, D.W.; Argo, J.J. Amending the law of contagion: A general theory of property transference. J. Assoc. Consum. Res. 2018, 3, 555-565. [CrossRef]

77. Nemeroff, C.; Rozin, P. The contagion concept in adult thinking in the United States: Transmission of germs and of interpersonal influence. Ethos 1994, 22, 158-186. [CrossRef]

78. Nemeroff, C.; Rozin, P. The makings of the magical mind: The nature and function of sympathetic magical thinking. In Imagining the Impossible: Magical, Scientific, and Religious Thinking in Children; Rosengren, K.S., Johnson, C.N., Harris, P.L.E., Eds.; Cambridge University Press: Cambridge, UK, 2000; pp. 1-34.

79. Rozin, P.; Fallon, A.E. A perspective on disgust. Psychol. Rev. 1987, 94, 23-41. [CrossRef]

80. Powell, W.; DiMaggio, P. The New Institutionalism in Organizational Analysis; University of Chicago Press: Chicago, IL, USA, 1991.

81. Moosmayer, D.C.; Chen, Y.; Davis, S.M. Deeds Not Words: A cosmopolitan perspective on the influences of corporate sustainability and NGO engagement on the adoption of sustainable products in China. J. Bus. Ethics 2019, 158, 135-154. [CrossRef]

82. Correia, J.; Dal Forno, A.J.; Marangoni, C.; Borges Valle, J.A. Waste management system in the clothing industry in Santa Catarina State Brazil: An initial overview. Manag. Environ. Qual. 2018, 29, 594-607. [CrossRef]

83. Testa, F.; Nucci, B.; Iraldo, F.; Appolloni, A.; Daddi, T. Removing obstacles to the implementation of LCA among SMEs: A collective strategy for exploiting recycled wool. J. Clean. Prod. 2017, 156, 923-931. [CrossRef]

84. Wang, L.; Shen, B. A product line analysis for eco-designed fashion products: Evidence from an outdoor sportswear brand. Sustainability 2017, 9, 1136. [CrossRef] 
85. Dobilaite, V.; Mileriene, G.; Juciene, M.; Saceviciene, V. Investigation of current state of pre-consumer textile waste generated at Lithuanian enterprises. Int. J. Cloth. Sci. Technol. 2017, 29, 491-503. [CrossRef]

86. Gregson, N.; Crang, M.; Botticello, J.; Calestani, M.; Krzywoszynska, A. Doing the 'dirty work' of the green economy: Resource recovery and migrant labour in the EU. Eur. Urban Reg. Stud. 2016, 23, 541-555. [CrossRef]

87. O'Reilly, S.; Kumar, A. Closing the loop An exploratory study of reverse ready-made garment supply chains in Delhi NCR. Int. J. Logist. Manag. 2016, 27, 486-510. [CrossRef]

88. Baier, D.; Rausch, T.M.; Wagner, T.F. The drivers of sustainable apparel and sportswear consumption: A segmented kano perspective. Sustainability 2020, 12, 2788. [CrossRef]

89. Bush, A.J.; Hair, J.F. An assessment of the mall intercept as a data collection method. J. Mark. Res. 1985, 22, 158-167. [CrossRef]

90. Johnson, R.B.; Onwuegbuzie, A.J. Mixed methods research: A research paradigm whose time has come. Educ. Res. 2004, 33, 14-26. [CrossRef]

91. Ziglio, E. The delphi method and its contribution to decision-making. In Gazing into the Oracle: The Delphi Method and Its Application to Social Policy and Public Health; Edler, M., Ziglio, E., Eds.; Jessica Kingsley Publishers: London, UK, 1996; pp. 3-33.

92. Ritch, E.L. Experiencing fashion: The interplay between consumer value and sustainability. Qual. Mark. Res. 2020, 23, 265-285. [CrossRef]

93. Gwozdz, W.; Steensen Nielsen, K.; Müller, T. An Environmental Perspective on Clothing Consumption: Consumer Segments and Their Behavioral Patterns. Sustainability 2017, 9, 762. [CrossRef]

94. Norris, L. Waste, dirt and desire: Fashioning narratives of material regeneration. Sociol. Rev. 2019, 67, 886-907. [CrossRef]

95. Ianole-Calin, R.; Francioni, B.; Masili, G.; Druica, E.; Goschin, Z. A cross-cultural analysis of how individualism and collectivism impact collaborative consumption. Resour. Conserv. Recycl. 2020, 157, 104762. [CrossRef]

96. Magnier, L.; Mugge, R.; Schoormans, J. Turning ocean garbage into products-Consumers' evaluations of products made of recycled ocean plastic. J. Clean. Prod. 2019, 215, 84-98. [CrossRef]

97. Weber, S.; Lynes, J.; Young, S.B. Fashion interest as a driver for consumer textile waste management: Reuse, recycle or disposal. Int. J. Consum. Stud. 2017, 41, 207-215. [CrossRef]

98. Grȩbosz-Krawczyk, M.; Siuda, D. Attitudes of young European consumers toward recycling campaigns of textile companies. Autex Res. J. 2019, 19, 394-399. [CrossRef]

99. Kamleitner, B.; Thurridl, C.; Martin, B.A.S. A Cinderella story: How past identity salience boosts demand for repurposed products. J. Mark. 2019, 83, 76-92. [CrossRef]

100. Saricam, C.; Erdumlu, N.; Silan, A.; Dogan, B.L.; Sonmezcan, G. Determination of consumer awareness about sustainable fashion. In Proceedings of the 17th World Textile Conference Autex 2017-Shaping the Future of Textiles, Corfu, Greece, 29-31 May 2017; Volume 254.

101. Stark, J.; Cudhea, M. The human side of the triangle: Using green textile standards to address social responsibility. WIT Trans. Ecol. Environ. 2010, 128, 525-536. [CrossRef]

102. Grasso, M.M. Recycling fabric waste-The challenge industry. J. Text. Inst. 1996, 87, 21-30. [CrossRef]

103. Raducanu, I. Evaluation and measuring the quality of ecological textiles corresponding to the eco-tex standard. Amfiteatru Econ. 2008, 10, 44-47.

104. Paço, A.; Leal Filho, W.; Ávila, L.V.; Dennis, K. Fostering sustainable consumer behavior regarding clothing: Assessing trends on purchases, recycling and disposal. Text. Res. J. 2020. [CrossRef]

105. Ozturk, S.; Engizek, N. An exploratory study on consumers attitudes towards ethical fashion consumption: Motivators and barriers. In Global and National Business Theories and Practice: Bridging the Past with the Future; Vrontis, D., Weber, Y., Tsoukatos, E., Eds.; Euromed Press: Marseille, France, 2017; pp. 1294-1308.

106. Yee, L.W.; Hassan, S.H.; Ramayah, T. Sustainability and philanthropic awareness in clothing disposal behavior among young Malaysian consumers. Sage Open 2016, 6. [CrossRef]

107. Wiederhold, M.; Martinez, L.F. Ethical consumer behaviour in Germany: The attitude-behaviour gap in the green apparel industry. Int. J. Consum. Stud. 2018, 42, 419-429. [CrossRef]

108. Norris, L. Recycling and reincarnation: The journeys of Indian saris. Mobilities 2008, 3, 415-436. [CrossRef]

109. Janigo, K.A.; Wu, J. Collaborative redesign of used clothes as a sustainable fashion solution and potential business opportunity. Fash. Pract. J. Des. Creat. Process Fash. Ind. 2015, 7, 75-98. [CrossRef]

110. Stieg, C. The sustainability gap. J. Inter. Des. 2006, 32, vii-xxi. [CrossRef] 
111. Hyun-Mee, J. Materialism and clothing post-purchase behaviors. J. Consum. Mark. 2013, 30, $530-537$. [CrossRef]

112. Park, H.J.; Lin, L.M. Exploring attitude-behavior gap in sustainable consumption: Comparison of recycled and upcycled fashion products. J. Bus. Res. 2020, 117, 623-628. [CrossRef]

113. Roberts, J.A. Will the real socially responsible consumer please step forward? Bus. Horiz. 1996, 39, 79-83. [CrossRef]

114. Childs, M.; Woo, H.; Kim, S. Sincerity or ploy? An investigation of corporate social responsibility campaigns. J. Prod. Brand Manag. 2019, 28, 489-501. [CrossRef]

115. Shrivastava, A.; Jain, G.; Kamble, S.S.; Belhadi, A. Sustainability through online renting clothing: Circular fashion fueled by instagram micro-celebrities. J. Clean. Prod. 2021, 278, 123772. [CrossRef]

116. Sung, K.; Cooper, T.; Kettley, S. Developing interventions for scaling up UK upcycling. Energies 2019, 12, 2778. [CrossRef]

117. Shim, S.; Kim, J.; Na, Y. An exploratory study on up-cycling as the sustainable clothing life at home. Fash. Text. 2018, 5, 14. [CrossRef]

118. Ji, Y.L.; Holly, H.; Jonhson, K.K.P.; Haewon, J. Investigating fashion disposition with young consumers. Young Consum. 2013, 14, 67-78. [CrossRef]

119. Goworek, H.; Fisher, T.; Cooper, T.; Woodward, S.; Hiller, A. The sustainable clothing market: An evaluation of potential strategies for UK retailers. Int. J. Retail Distrib. Manag. 2012, 40, 935-955. [CrossRef]

120. Zurga, Z.; Hladnik, A.; Tavcer, P.F. Environmentally sustainable apparel acquisition and disposal behaviours among slovenian consumers. Autex Res. J. 2015, 15, 243-259. [CrossRef]

121. Grasso, M.M.; McEnally, M.; Widdows, R.; Herr, D.G. Consumer behavior toward recycled textile products. J. Text. Inst. 2000, 91, 94-106. [CrossRef]

122. Norum, P.S. Towards sustainable clothing disposition: Exploring the consumer choice to use trash as a disposal option. Sustainability 2017, 9, 1187. [CrossRef]

123. Armstrong, C.M.; Niinimäki, K.; Kujala, S.; Karell, E.; Lang, C. Sustainable product-service systems for clothing: Exploring consumer perceptions of consumption alternatives in Finland. J. Clean. Prod. 2015, 97, 30-39. [CrossRef]

124. Meng, M.D.; Leary, R.B. It might be ethical, but I won't buy it: Perceived contamination of, and disgust towards, clothing made from recycled plastic bottles. Psychol. Mark. 2019. [CrossRef]

125. Yu, S.; Lee, J. The effects of consumers' perceived values on intention to purchase upcycled products. Sustainability 2019, 11, 1034. [CrossRef]

126. Botticello, J. Between classification, objectification, and perception: Processing secondhand clothing for recycling and reuse. Textile 2012, 10, 164-183. [CrossRef]

127. Laitala, K. Consumers' clothing disposal behaviour-A synthesis of research results. Int. J. Consum. Stud. 2014, 38, 444-457. [CrossRef]

128. EUKN. The Circular City. Lessons From Europe. Factsheet for Policy Lab Netherlands; European Urban Knowledge Network: The Hague, The Netherlands, 2015.

129. de Coverly, E.; McDonagh, P.; O'Malley, L.; Patterson, M. Hidden Mountain: The social avoidance of waste. J. Macromark. 2008, 28, 289-303. [CrossRef]

130. Derksen, L.; Gartrell, J. The social context of recycling. Am. Sociol. Rev. 1993, 58, 434-442. [CrossRef]

131. Veelaert, L.; Bois, E.D.; Moons, I.; Pelsmacker, P.D.; Hubo, S.; Ragaert, K. The identity of recycled plastics: A vocabulary of perception. Sustainability 2020, 12, 1953. [CrossRef]

132. Stanes, E.; Gibson, C. Materials that linger: An embodied geography of polyester clothes. Geoforum 2017, 85, 27-36. [CrossRef]

133. Soroudi, A.; Jakubowicz, I. Recycling of bioplastics, their blends and biocomposites: A review. Eur. Polym. J. 2013, 49, 2839-2858. [CrossRef]

Publisher's Note: MDPI stays neutral with regard to jurisdictional claims in published maps and institutional affiliations. 